\title{
Origins of Archaeal Tetraether Lipids in Sediments: Insights From Radiocarbon Analysis
}

\section{Citation}

Shah Walter, Sunita, Gesine Mollenhauer, Naohiko Ohkouchi, Timothy I. Eglinton, and Ann Pearson. 2008. Origins of archaeal tetraether lipids in sediments: insights from radiocarbon analysis. Geochimica et Cosmochimica Acta 72, no. 18: 4577-4594. doi:10.1016/ j.gca.2008.06.021.

\section{Permanent link}

http://nrs.harvard.edu/urn-3:HUL.InstRepos:41543200

\section{Terms of Use}

This article was downloaded from Harvard University's DASH repository, WARNING: This file should NOT have been available for downloading from Harvard University's DASH repository.

\section{Share Your Story}

The Harvard community has made this article openly available.

Please share how this access benefits you. Submit a story.

Accessibility 
3 Sunita R. Shah ${ }^{* 1}$, Gesine Mollenhauer ${ }^{2}$, Naohiko Ohkouchi $^{3}$, Timothy I. Eglinton ${ }^{4}$, Ann Pearson ${ }^{1}$

4

$5 \quad{ }^{1}$ Department of Earth and Planetary Sciences, Harvard University, Cambridge, MA 02138, USA

$6 \quad{ }^{2}$ Alfred Wegener Institute for Polar and Marine Research, D-27570 Bremerhaven, Germany

$7 \quad{ }^{3}$ Institute for Research on Earth Evolution, Japan-Agency for Marine-Earth Science and

8 Technology, Yokosuka 237-0061, Japan

$9{ }^{4}$ Department of Marine Chemistry and Geochemistry, Woods Hole Oceanographic Institution,

10 Woods Hole, MA 02543, USA

11

12

$13 *$ Corresponding author: $\underline{\text { shah@ fas.harvard.edu }}$

14

15 This manuscript has been submitted to GCA and revised according to reviewers' suggestions. 
Understanding the supply and preservation of glycerol dibiphytanyl glycerol tetraethers (GDGTs) in marine sediments helps inform their use in paleoceanography. Compound-specific radiocarbon measurements of sedimentary alkenones from multiple environments have been used to gain insight into processes that affect $\mathrm{U}_{37}^{\mathrm{K}^{\prime}}$ paleo-temperature reconstructions. Similar analyses are warranted to investigate how analogous processes affecting GDGTs impact TEX 86 paleotemperatures. Here we present radiocarbon measurements on individual GDGTs from Bermuda Rise and Santa Monica Basin sediments and discuss the results in the context of previous studies of co-depositional alkenones and foraminifera. The ${ }^{14} \mathrm{C}$ contents of GDGTs and planktonic foraminifera in Bermuda Rise are very similar, suggesting a local source; and $\mathrm{TEX}_{86^{-}}$ derived temperatures agree more closely with foraminiferal temperatures than do $U_{37}^{K^{\prime}}$ temperatures. In contrast, GDGTs in Santa Monica Basin are depleted in ${ }^{14} \mathrm{C}$ relative to both alkenones and foraminifera, and $\mathrm{TEX}_{86}$ temperatures agree poorly with known surface water values. We propose three possible factors that could explain these results: (i) GDGTs may be labile relative to alkenones during advective transport through oxic waters; $(\mathrm{ii})$ archaeal production deep in the water column may contribute ${ }^{14} \mathrm{C}$-depleted GDGTs to sediments; and (iii) some GDGTs also may derive from sedimentary archaeal communities. Each of these three processes is likely to occur with varying relative importance depending on geographic location. The latter two may help to explain why $\mathrm{TEX}_{86}$ temperature reconstructions from Santa Monica Basin do not appear to reflect actual sea surface temperatures. Terrigenous GDGTs are unlikely to be major contributors to Bermuda Rise or Santa Monica Basin sediments, based on values of the BIT index. The results also indicate that the crenarchaeol regioisomer is governed by processes different from other GDGTs. Individual measurements of the crenarchaeol regioisomer are significantly depleted in ${ }^{14} \mathrm{C}$ relative to co-occurring GDGTs, indicating an alternative origin for this compound that presently remains unknown. Re-examination of the contribution of crenarchaeol regioisomer to the $\mathrm{TEX}_{86}$ index shows that it is a significant influence on the sensitivity of temperature reconstructions. 
Archaea are found ubiquitously in the water column (e.g., Fuhrman et al., 1992; DeLong

et al., 1992; Karner et al., 2001; Herndl et al., 2005) and in the sediments (e.g., Vetriani et al., 1998; Vetriani et al., 1999; Teske et al., 2002) of the modern ocean. The record of archaea through geologic time is preserved by their characteristic membrane lipids, which are abundant in marine sediments since the Cretaceous (Kuypers et al., 2002; Schouten et al., 2003). A significant correlation has been observed between the composition of particular archaeal lipids in modern surface sediments, the glycerol dibiphytanyl glycerol tetraethers (GDGTs, molecular structures in Figure 1) and overlying sea surface temperature. This correlation has inspired a paleotemperature proxy, the $\mathrm{TEX}_{86}$ index (Schouten et al., 2002). The correlation between sedimentary GDGTs and sea surface temperatures suggests that GDGTs found in sediments originate predominantly from surface waters. Although marine archaea are found at all depths in the water column, primary export of GDGTs to the sediments is thought to occur by processes that dominantly exist in the upper water column (e.g., consumption by zooplankton and packaging into fecal pellets (Schouten et al., 2002; Wakeham et al., 2003; Wuchter et al., 2006)).

There is a need for greater understanding of the many potential sources and processes that ultimately could affect the preserved GDGT assemblages, and the long-chain alkenones produced by haptophyte algae (Marlowe et al., 1984) may be good models to help understand these processes. Alkenone abundances are the basis of the $\mathrm{U}_{37}^{\mathrm{K}^{\prime}}$ paleotemperature index (Brassell et al., 1986). They have been demonstrated to be more resistant to degradation than other lipid biomarker compounds (Grimalt et al., 2000 and references therein). GDGTs also are thought to be relatively resistant to degradation because of their ether linkages and isoprenoid alkyl groups (Figure 1) (Sinninghe Damsté et al., 2002, Schouten et al., 2004).

Compound-specific radiocarbon measurements have been made on co-depositional alkenones and planktonic foraminifera from the sediments of the Bermuda Rise (Ohkouchi et al., 2002); the Benguela Upwelling System off Namibia (Mollenhauer et al., 2003); the Chilean 
1 Margin, off the coast of northwest Africa, and the South China Sea (Mollenhauer et al., 2005);

2 and Santa Barbara and Santa Monica Basins (Mollenhauer and Eglinton, 2007). The ${ }^{14} \mathrm{C}$ content

3 of planktonic foraminifera reflects the ${ }^{14} \mathrm{C}$ content of dissolved inorganic carbon (DIC) in surface

4 seawater. Due to their large size and density, they are thought to settle directly to the seafloor

5 and reflect the true depositional age of the sediment. Because haptophyte algae also incorporate

6 dissolved inorganic carbon (DIC) from surface seawater, alkenone and foraminiferal ${ }^{14} \mathrm{C}$ contents

7 would be identical if their export and burial processes were the same. However, alkenones

8 generally are found to be depleted in ${ }^{14} \mathrm{C}$ compared to planktonic foraminifera (Ohkouchi et al.,

9 2002; Mollenhauer et al., 2003; Mollenhauer et al., 2005; Mollenhauer and Eglinton, 2007).

10 This could result from various post-depositional processes such as bioturbation; the addition of

11 pre-aged alkenones from an erosional source; or aging during resuspension, lateral transport and

12 re-deposition from distant sediments. The largest ${ }^{14} \mathrm{C}$ offsets between alkenones and planktonic

13 foraminifera are found in the Bermuda Rise (Figure 2, Ohkouchi et al., 2002), and the smallest

14 offsets are from the South China Sea and off northwest Africa (Figure 2, Mollenhauer et al.,

15 2005). Multiple lines of evidence suggest that the primary control on the ${ }^{14} \mathrm{C}$ content of

16 alkenones is the proportion of pre-aged alkenones delivered by lateral advective transport

17 (Ohkouchi et al., 2002; Mollenhauer et al., 2003; Mollenhauer et al., 2005; Mollenhauer and

18 Eglinton, 2007). The presumed source of this exogenous material is re-suspension from

19 sediments originally deposited elsewhere. The recalcitrance of alkenone lipids, or potentially

20 their intimate association either with coccolith biominerals or with the fine-grained clay mineral

21 fraction of sediments, permits their survival over these distances. The relative proportion of the

22 advected material from allochthonous sources is location-specific and determined by spatial

23 variations in surface-water productivity, local bottom currents and seafloor topography.

24 Like alkenones, archaeal GDGTs are large hydrophobic lipids and therefore also may 25 associate with the fine-grained sediment fraction. Recently radiocarbon measurements were 26 reported for co-depositional alkenones, foraminifera, and in a subset of these samples, for the 27 GDGT crenarchaeol (Figure 2, Mollenhauer et al., 2007). Like alkenones, crenarchaeol 
appeared to show an age offset relative to planktonic foraminifera, offering preliminary evidence that crenarchaeol is indeed re-mobilized and advectively transported with bottom currents. However, the measurements also suggested that crenarchaeol may not be as resistant to degradation during transport in the nepheloid layer as alkenones, as crenarchaeol also appears to be less aged relative to alkenones with increasing transport time (Mollenhauer et al., 2007).

Determining the relative proportions of the various sources of GDGTs found in sediments is further complicated by the possibility that not all GDGTs are necessarily synthesized in the surface ocean. Archaea are abundant members of the total microbial community in the deep water column (e.g., Karner et al., 2001; Herndl et al., 2005). Mesopelagic archaea, as well as populations living in the sediments, could contribute to the total pool of sedimentary GDGTs.

Here we report ${ }^{14} \mathrm{C}$ measurements for archaeal GDGTs obtained from the same Bermuda Rise and Santa Monica Basin samples for which alkenone and foraminiferal data are available (Pearson et al., 2000; Ohkouchi et al., 2002; Mollenhauer and Eglinton, 2007). These sites represent the locations having the largest (Bermuda Rise) and smallest (Santa Monica Basin, among sites with more than three alkenone measurements) ${ }^{14} \mathrm{C}$ offsets between corresponding planktonic foraminifera and alkenones (Figure 2). The pattern of radiocarbon age offsets of GDGTs should indicate whether GDGTs are affected by re-suspension and advection processes over the same timescales as experienced by the alkenones found within identical sediments.

\section{COMPARISON OF SETTINGS}

Previous paleoceanographic studies have been conducted in both Bermuda Rise (e.g., Keigwin, 1996; Sachs and Lehman, 1999) and Santa Monica Basin sediments (Christensen et al., 1994; Hagadorn et al., 1995). Bermuda Rise is a North Atlantic sediment drift site where rapid accumulation results from advection and focusing of detrital material (Keigwin et al., 1996). Bermuda Rise sediments are oxic at the surface, and the rapid accumulation rate minimizes the effects of bioturbation and allows reconstruction of high-resolution paleoproxy records. 
1 However, a large fraction of the alkenones contributed to Bermuda Rise sediments by advection

2 is thought to originate in the Canadian Margin off the coast of Nova Scotia (Ohkouchi et al.,

3 2002). This advected detrital fraction contains alkenones having values of $U_{37}^{K^{\prime}}$ reflecting 4 formation in waters of colder sea surface temperature (SST) and depleted ${ }^{14} \mathrm{C}$ contents

5 (Ohkouchi et al., 2002); it also contains other lipid biomarkers (Ohkouchi et al., submitted). Representing a very different setting, Santa Monica Basin (SMB) is part of the California Borderland Basin system. Its $905-\mathrm{m}$ water column is suboxic below the sill depth of $740 \mathrm{~m}$. High rates of organic matter preservation and laminated, anoxic sediments also allow

9 paleoceanographic reconstructions with high temporal resolution (Christensen et al., 1994; Hagadorn et al., 1995). Very recently-deposited material is preserved in the central SMB, as is evident from observations of bomb radiocarbon in planktonic foraminifera (Pearson et al, 2000; Mollenhauer and Eglinton, 2007) and alkenones (Mollenhauer and Eglinton, 2007). Bomb radiocarbon derived from nuclear bomb testing in the 1950s and 1960s is observed as a spike in

14 the abundance of ${ }^{14} \mathrm{C}$, and it therefore signals products derived from surface seawater over the 15 last 50 years. It is found in the top $2.5 \mathrm{~cm}$ of sediment from the depositional center of Santa Monica Basin. However, like at Bermuda Rise, pre-aged organic material, including alkenones, also appears to be advectively delivered to the center of Santa Monica Basin (Mollenhauer and Eglinton, 2007). Here, the advected fraction of alkenones is thought to have been originally deposited on the adjacent California shelf (Mollenhauer and Eglinton, 2007).

\section{EXPERIMENTAL}

\subsection{Sampling and lipid extraction}

Archaeal GDGTs were isolated from archived lipid extracts obtained from cores previously processed for radiocarbon analysis of alkenones. Bermuda Rise samples are from 27 cores BC9 $\left(33^{\circ} 41.6^{\prime} \mathrm{N}, 57^{\circ} 36.7^{\prime} \mathrm{W}\right)$, GGC5 $\left(33^{\circ} 41.5^{\prime} \mathrm{N}, 57^{\circ} 34.5^{\prime} \mathrm{W}\right)$ and GPC5 $\left(33^{\circ} 41.2^{\prime} \mathrm{N}\right.$, 
$157^{\circ} 36.9^{\prime} \mathrm{W}$ ) described in Ohkouchi et al. (2002). Total lipids were extracted, separated into

2 acidic and neutral fractions and the neutral fraction was further separated into three polarity

3 fractions (see Ohkouchi et al., 2005 for full method). For this study, the alcohol polarity fraction

4 (eluted off $\mathrm{SiO}_{2}$ column in chloroform $\left(\mathrm{CH}_{2} \mathrm{Cl}_{2}\right) /$ methanol $(\mathrm{MeOH})(95: 5$, v/v)) was further

5 fractionated using Biotage Flash 12i pressurized chromatography (12 X 150mm column, 32-

$663 \mu \mathrm{m}$ particle size) into three sub-fractions eluting in hexane/ethyl acetate (EtOAc) (75:25, v/v),

7 EtOAc, and $\mathrm{MeOH}$ (modified from fractions described in Pearson et al., 2001). GDGTs were

8 found in the fraction eluting in 100\% EtOAc. Santa Monica Basin samples from 6-7 cm and 32-

$934 \mathrm{~cm}$ are from core SMB-900 $\left(33^{\circ} 46.9^{\prime} \mathrm{N}, 118^{\circ} 49^{\prime} \mathrm{W}\right)$ previously described in Mollenhauer and 10 Eglinton (2007). Total lipids were extracted and the alcohol/sterol fraction was obtained 11 similarly to the process described for Bermuda Rise samples (Ohkouchi et al., 2005; 12 Mollenhauer and Eglinton, 2007). The Santa Monica Basin samples from 1-2 cm, 2-3 cm and 3$134 \mathrm{~cm}$ are from the Pulse- 32 core $\left(33^{\circ} 44.0^{\prime} \mathrm{N}, 118^{\circ} 50.0^{\prime} \mathrm{W}\right)$ previously described in Pearson et al. 14 (2000) and Pearson et al. (2001). Total lipids were extracted and separated into polarity fractions 15 using Biotage Flash pressurized chromatography by the process described above for Bermuda 16 Rise samples.

\subsection{GDGT isolation and purification}

Individual GDGTs were isolated from polarity fractions using a two-step highperformance liquid chromatography (HPLC) method. Samples first are separated by normal-

22 phase preparative HPLC (Smittenberg et al., 2002; Ingalls et al., 2006). Subsequently each

23 fraction is cleaned of co-eluting pigments by reverse-phase chromatography (Ingalls et al., 2006;

24 Shah and Pearson, 2007). Compound identifications, peak elution times and relative abundances of GDGTs for each sample first were obtained by injecting 3-5\% of the total sample and detecting the peaks by APCI-MS (Hopmans et al., 2000) monitoring $\mathrm{m} / \mathrm{z}$ 1250-1350 for Santa

27 Monica Basin samples and $m / z$ 1000-1350 for Bermuda Rise samples. One Santa Monica Basin 
1 sample, from 6-7cm sediment depth, was re-injected monitoring $m / z$ 1000-1350. GDGTs then

2 were isolated from the remainder of the sample by time-based fraction collection of between 6

3 and 9 individual HPLC injections. Before pooling, the contents of each time-based collection

4 window were determined by flow injection analysis (FIA). The isolated GDGTs were pooled

5 into four fractions: GDGT-0, GDGTs 1-3, crenarchaeol, and crenarchaeol regioisomer. GDGT

6 numerical designations refer to the total number of cyclopentyl rings (Sinninghe Damsté et al.,

7 2002).

8 The normal-phase GDGT collections from all sediment depths and both locations were

9 often colored green or brown, indicating co-elution of pigmented contaminants. GDGTs were

10 purified of these contaminants by reverse-phase HPLC (Shah and Pearson, 2007) in one or two

11 injections, depending on sample size. Purified GDGTs eluted over $<2 \mathrm{~min}$, and the contents of

12 each collection were again verified by FIA. As each sample was processed with only one or two

13 reverse-phase injections, each purified sample was collected in a maximum of $4 \mathrm{ml}$ of running

14 solvent. This has been shown to result in a minimal $(0.03 \mu \mathrm{g} / \mathrm{ml})$ process blank which is

15 considerably less than the blank added by closed-tube combustion and other sample-preparation

16 processes (Shah and Pearson, 2007). Aggregated fractions were colorless and dried to a white

17 powder.

18 The expected carbon content of each sample was determined by comparing the FIA peak

area to a correlation of the FIA peak area of previously processed samples and their carbon

20 content as determined by quantification of $\mathrm{CO}_{2}$ from combusted samples $\left(\mathrm{r}^{2}=0.88\right)$. The

21 detection limit for GDGTs by this method is $0.3 \mu \mathrm{g}$ of carbon $(\mu \mathrm{gC})$. In most cases, samples

22 estimated to have less than $25 \mu \mathrm{gC}$ were combined with other GDGT fractions from the same

23 sediment depth before combustion. For example, GDGT-0 (9 $\mu \mathrm{gC})$, GDGT 1-3 (8 $\mu \mathrm{gC})$,

24 crenarchaeol $(22 \mu \mathrm{gC})$ and crenarchaeol regioisomer $(2 \mu \mathrm{gC})$ from 1-2 $\mathrm{cm}$ in Bermuda Rise were

25 combined into a single ${ }^{14} \mathrm{C}$ measurement on $41 \mu \mathrm{gC}$. 
Samples were transferred to quartz tubes, dried under ultra-pure $\mathrm{N}_{2}$, evacuated to $10^{-5}$

torr, flame-sealed, and combusted according established methods. The resulting $\mathrm{CO}_{2}$ was quantified and submitted to NOSAMS (http://www.nosams.whoi.edu/) for AMS measurement in 2006 and 2007.

\subsection{AMS measurement and blank corrections}

The size of samples submitted for radiocarbon measurement ranged from 6 to $219 \mu \mathrm{gC}$. All samples were processed using small-sample techniques (Pearson et al., 1998) as no sample had more than $300 \mu \mathrm{gC}$. The four samples isolated from $32-34 \mathrm{~cm}$ in Santa Monica Basin (GDGT-0, GDGTs 1-3, crenarchaeol, and crenarchaeol regioisomer) each had less than $25 \mu \mathrm{gC}$ and were not combined before combustion. Because these samples would have had insufficient carbon for individual AMS measurement at NOSAMS, they were diluted with a known ratio of radiocarbon-dead $\mathrm{CO}_{2}$. Calculation of the corrected values of $\Delta^{14} \mathrm{C}$ and the propagation of error associated with this dilution (Pearson et al., 1998) is described in Electronic Annex EA-1.

All samples were further corrected for sample processing blanks as described in Shah and Pearson (2007). This is particularly important for smaller samples as background carbon can contribute up to $2 \mu \mathrm{gC}$ of the total sample. All radiocarbon values are reported here as values of $\Delta^{14} \mathrm{C}$ (Stuiver and Polach, 1977). In most cases, these values have been corrected for fractionation effects using measured $\delta^{13} \mathrm{C}$ values from the same sample. If $\delta^{13} \mathrm{C}$ was not measured due to small sample size, $\delta^{13} \mathrm{C}$ was assumed to be equal to an abundance-weighted average of other measurements from the same location and sediment depth. Values of $\Delta^{14} \mathrm{C}$ were calculated from the NOSAMS-reported values of $\mathrm{f}_{\mathrm{m}}$ following the conventions of Stuiver and Polach (1977): 


$$
\Delta^{14} \mathrm{C}=\left(\mathrm{f}_{\mathrm{m}} * \mathrm{e}^{\lambda *\left(1950-\mathrm{y}_{\mathrm{m}}\right)}-1\right) * 1000
$$

2 where $\lambda=1 / 8267$ and $y_{m}$ is the year measured.

Previously measured values for alkenones and foraminifera from these cores were

4 reported as conventional radiocarbon ages (Ohkouchi et al., 2002; Mollenhauer et al., 2003; Mollenhauer et al., 2005) or $\mathrm{f}_{\mathrm{m}}$ values (Mollenhauer et al., 2003; Mollenhauer et al., 2005; Mollenhauer and Eglinton, 2007). To relate these reported values to the conventions used here, converted values of $\Delta^{14} \mathrm{C}$ were calculated from $\mathrm{f}_{\mathrm{m}}$ and/or from radiocarbon age (radiocarbon age $=-8033 * \ln \left(f_{m}\right)$, Stuiver and Polach, 1977). Alkenones and foraminifera from Bermuda Rise samples were assumed to have been measured in 2000. Adjusting these $\Delta^{14} \mathrm{C}$ values for the additional decay that occurred between the year they were measured and the years our GDGTs were measured (2006-2007) would allow a more exact comparison of their radiocarbon contents. However, as this correction would have amounted to $\leq 1 \%$, no correction was made. Foraminiferal $\Delta{ }^{14} \mathrm{C}$ values reported in Pearson et al. (2000) had been corrected for decay occurring since deposition to the sediment. This decay correction was removed for appropriate comparison with $\Delta^{14} \mathrm{C}$ values in this study, which were not decay corrected.

\subsection{Calculation of TEX S6 $_{86}$ and BIT index values}

19

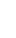

according to the equation defined in Schouten et al. (2002). Using our methods and HPLC instrument, the error associated with $\mathrm{TEX}_{86}$ values has previously been established at $0.01 \mathrm{TEX}_{86}$ units. Branched and isoprenoid tetraether (BIT) index values were also calculated according to Hopmans et al. (2004) for all sediment horizons of Bermuda Rise. It was only possible to measure the BIT index on one sediment horizon for Santa Monica Basin: 6-7cm. 


\section{RESULTS}

2

The lipid abundances of all samples had the characteristic marine archaeal GDGT profile: abundant GDGT-0 and crenarchaeol and smaller quantities of GDGT-1, GDGT-2, GDGT-3, and crenarchaeol regioisomer. Relative abundances are reported in electronic annex EA-2. TEX 86 values were calculated based on these abundances (Schouten et al., 2002) and ranged from 0.54 to 0.72 in sediments from the Bermuda Rise (Table EA2-1). Using the most recent TEX 86 calibration (Kim et al., 2008), these $\mathrm{TEX}_{86}$ values translate to temperatures between $20^{\circ} \mathrm{C}$ and $30^{\circ}$ C. TEX 86 values calculated from Santa Monica Basin sediments were much more variable and ranged from 0.49 to 0.77 within just four centimeters of sediment depth. Despite their much more recent sediment ages (Figure 3) (Mollenhauer and Eglinton, 2007), the temperatures reconstructed from these values were between $17^{\circ} \mathrm{C}$ and $32^{\circ} \mathrm{C}$ (Kim et al., 2008). BIT values for all sediment horizons from the Bermuda Rise were at or below 0.27 with an average value of 0.12. It was only possible to measure branched tetraether compounds on one sediment horizon from Santa Monica Basin: 6-7cm. This BIT value was 0.16. These values fall within the range of open marine samples (Hopmans et al., 2004).

In sediments from the Bermuda Rise, archaeal GDGTs have values of $\Delta^{14} \mathrm{C}$ that generally fall between the values for planktonic foraminifera and alkenones, although they are more similar to the foraminifera (Figure 3a). The mass-weighted averages for total GDGTs are no more than $135 \%$ more ${ }^{14} \mathrm{C}$-depleted than planktonic foraminifera, and sometimes are more ${ }^{14} \mathrm{C}$ enriched (by up to 18\%o). Below $6 \mathrm{~cm}$ sediment depth in particular, the offset between planktonic foraminiferal and average GDGT radiocarbon content is even smaller: the maximum ${ }^{14} \mathrm{C}$-depletion for GDGTs relative to foraminifera is $28 \%$. In many horizons at these depths, the difference is less than the measurement uncertainty. When expressed in terms of radiocarbon years, the average age difference between GDGTs and foraminifera in the top $6 \mathrm{~cm}$ of the core is $950 \pm 500$ years. These horizons correspond to intervals with the greatest inferred input of 
advected material (Ohkouchi et al., submitted). Between $6 \mathrm{~cm}$ and $345 \mathrm{~cm}$ the offset is between 5 and 75 years, and below $350 \mathrm{~cm}$ it is between 440 and 2110 years.

The $\Delta^{14} \mathrm{C}$ values of co-depositional planktonic foraminifera and alkenones also differ. However, in contrast to the GDGTs, when these alkenone-foraminiferal differences are expressed as radiocarbon ages, the offset does not change appreciably or systematically with depth $(4000 \pm 2000$ years $)$ and is larger than the difference between foraminifera and GDGTs (Ohkouchi et al., 2002). These results show that there must be different mechanisms controlling the ${ }^{14} \mathrm{C}$ contents of sedimentary GDGTs and alkenones in Bermuda Rise sediments.

In contrast to the patterns seen in Bermuda Rise, archaeal GDGTs from Santa Monica Basin generally are more depleted in ${ }^{14} \mathrm{C}$ compared to both foraminifera and alkenones (Figure 3b), agreeing with data previously published for this location (Pearson et al., 2001). At each depth, the $\Delta^{14} \mathrm{C}$ values of archaeal GDGTs fall between the $\Delta^{14} \mathrm{C}$ values of the planktonic and benthic foraminifera. The notable exception is crenarchaeol regioisomer, which is significantly more depleted than any compound (Figure $3 \mathrm{~b}$ ) other than petroleum-derived $n$-alkanes measured within these horizons (Pearson et al., 2000; Pearson et al., 2001).

The abundance-weighted average of the other GDGTs (calculated without contribution from the anomalous crenarchaeol regioisomer) is more ${ }^{14} \mathrm{C}$-depleted than planktonic foraminifera by between $30 \%$ and $160 \%$, with all of the individual differences being significant. The higher $\Delta^{14} \mathrm{C}$ values in the planktonic foraminifera are greatly influenced by the bomb radiocarbon evident in the $\Delta^{14} \mathrm{C}$ values from $0-0.75 \mathrm{~cm}, 0.75-1.5 \mathrm{~cm}$ and $1.5-2.5 \mathrm{~cm}$, and it would be inaccurate to express the corresponding GDGT-foraminiferal differences in terms of radiocarbon years. But importantly, archaeal GDGTs do not show a detectable influence from bomb radiocarbon at any depth, with the possible exception of GDGT-0 from $0.75-1.5 \mathrm{~cm}$ depth (-67\%, which is $15 \%$ higher than pre-bomb surface waters in this region). GDGTs also are more ${ }^{14} \mathrm{C}$-depleted than co-depositional alkenones by up to $110 \%$, with some of the individual differences being significant and others within measurement errors. As with the GDGTs and planktonic foraminifera, this average difference is largest in the $0.75-1.5 \mathrm{~cm}$ horizon because of 
1 the bomb radiocarbon evident in the alkenones. In the pre-bomb sediment horizons, $\Delta{ }^{14} \mathrm{C}$ values

2 of alkenones and GDGTs are within measurement error of each other, but in post-bomb horizons,

3 GDGTs are significantly ${ }^{14} \mathrm{C}$-depleted relative to alkenones. These patterns again show that the

4 mechanisms that control the ${ }^{14} \mathrm{C}$ contents of alkenones and GDGTs must be different.

5 To decouple post-depositional processes from the effects of surface ocean conditions

6 (e.g., surface ocean reservoir age and time-varying ${ }^{14} \mathrm{C}$ content), comparisons can be made

7 between the ${ }^{14} \mathrm{C}$ contents of foraminifera, alkenones and GDGTs within each sediment horizon.

8 Plotting the $\Delta^{14} \mathrm{C}$ values of alkenones and GDGTs relative to their co-occurring planktonic

9 foraminifera shows characteristic relationships for Bermuda Rise (Figure 4a) and Santa Monica

10 Basin (Figure $4 \mathrm{~b}$ ). The similarity between the $\Delta{ }^{14} \mathrm{C}$ values of GDGTs and planktonic

11 foraminifera in Bermuda Rise is evident by the proximity of these samples to the 1:1 line

12 (Figure 4a). This contrasts with the relationship in Santa Monica Basin, where GDGTs plot 13 significantly offset from the 1:1 line (Figure $4 \mathrm{~b}$ ). The question then becomes whether such 14 patterns are best explained by different sources or by post-depositional processes that affect the 15 GDGTs and alkenones.

\section{DISCUSSION}

\subsection{Processes with potential to cause a ${ }^{14} \mathrm{C}$ offset} sedimentary alkenones is not the same as the pre-aged component of sedimentary GDGTs. The production and export of alkenones is greater over the Nova Scotian Margin (the source of

24 advectively-delivered material to the Bermuda Rise) compared to the Sargasso Sea. This 25 difference enhances the importance of advectively delivered alkenones relative to the supply of 
1 differences in GDGT production have not been quantified, Crenarchaeota are found throughout

2 the oceans, and the distant advective source may not dominate GDGT sources in the same way.

GDGTs also may be more labile than alkenones. Alkenones are offset from planktonic foraminifera by up to 7100 years at Bermuda Rise (Ohkouchi et al., 2001); GDGTs may degrade during transport over such long temporal histories, effectively increasing the importance of local sources. In contrast, GDGTs may survive the shorter timescale of transport processes in Santa Monica Basin (alkenone-foraminifera offset up to 430 years; Mollenhauer and Eglinton, 2007). Although degradation could help to explain the general absence of ${ }^{14} \mathrm{C}$-depleted GDGTs at Bermuda Rise, this mechanism predicts that GDGTs would have ${ }^{14} \mathrm{C}$ contents similar to alkenones at Santa Monica Basin. Because they do not, anomalously aged source(s) of GDGTs are also required to explain the depletion in ${ }^{14} \mathrm{C}$. Lability effects alone cannot cause GDGTs to be more ${ }^{14} \mathrm{C}$-depleted than alkenones. GDGTs could be contributed to Santa Monica Basin by archaea that incorporate ${ }^{14} \mathrm{C}$-depleted DIC from the deep, suboxic water column. Alternatively, archaeal communities living within anoxic, organic-rich Santa Monica Basin sediments could be synthesizing GDGTs from old sedimentary carbon substrates. Finally, it is possible that there could be contributions of pre-aged GDGTs from terrestrial sources, because of the greater proximity to continental runoff than at Bermuda Rise. Each of these options is discussed below.

\subsubsection{Preferential degradation of GDGTs during lateral advection}

Detrital material contributed to Bermuda Rise sediments is thought to originate from the Canadian Margin, off the coast of Nova Scotia (Keigwin, 1996; Ohkouchi et al., 2002). This region experiences abundant production of haptophyte algae; and as indicated by the radiocarbon age of alkenones delivered to Bermuda Rise, $\sim 7000$ years pass between production and final deposition (Figure 2; Ohkouchi et al., 2002; Ohkouchi et al., submitted). In contrast, in the depositional centers of the California Borderland Basins, the age offset between planktonic foraminifera and alkenones is only $340 \pm 60$ years (calculated from pre-bomb sediment horizons 
only, Mollenhauer and Eglinton, 2007). This smaller age offset reflects a much more proximal and rapid source for delivery of alkenones: local transport from the adjacent California shelf (Mollenhauer and Eglinton, 2007).

Patterns of GDGT ages do not conform to the above patterns observed for alkenones. These differences could be partially caused by unequal lability. Alkenones are more resistant to degradation than many other lipids (Grimalt et al., 2000 and references therein). Limited information exists about the recalcitrance of GDGTs relative to each other, to alkenones, or to other lipid biomarkers (Sinninghe Damsté et al., 2002; Schouten et al., 2004; Huguet, 2007). If GDGTs are preferentially degraded during advection through an oxic nepheloid layer, the contribution of exogenous GDGTs would be reduced as a function of transport time and distance. Large radiocarbon offsets between alkenones and foraminifera would indicate a long time spent in re-suspension. This would in turn correspond to smaller radiocarbon offsets between GDGTs and foraminifera, because the contribution from advected GDGTs would be minimal and most GDGTs would be local. Indeed, at Bermuda Rise, the average difference between the radiocarbon ages of GDGTs and foraminifera ( $820 \pm 800$ years) is much smaller than the difference between alkenones and foraminifera ( $4000 \pm 2000$ years).

In Santa Monica Basin where the delay between surface export and burial is short, and alkenone sources are primarily local, the radiocarbon ages of GDGTs and alkenones would be expected to be within measurement errors, and both would be $<400$ years different from foraminifera. It is therefore surprising that the GDGT-foraminifera offset generally is larger and much more variable (275 to 630 years for pre-bomb depths, or 1280 to 1600 years for post-bomb depths; Figure 4). These older ages indicate that additional influences on the sedimentary GDGT pool are also required in Santa Monica Basin.

Observations from the Benguela Upwelling System are consistent with the hypothesized lability of GDGTs (Mollenhauer et al., 2007). Radiocarbon contents of crenarchaeol, alkenones, and planktonic foraminifera from two transects across the continental shelf indicated that crenarchaeol is more rapidly degraded than alkenones. Like our results for Bermuda Rise, a 
1 smaller fraction of pre-aged crenarchaeol contributed to the sediments farther downslope on the

2 continental margin, which in this case is also increased transport distance. In the Benguela

3 Upwelling System, alkenones often have the largest radiocarbon age offset of all measured

4 components relative to foraminifera (Mollenhauer et al., 2003; Mollenhauer et al., 2007). The

5 more labile short-chain fatty acids are very slightly different from planktonic foraminiferal ages

6 (Mollenhauer et al., 2003). Although a direct comparison between fatty acids, alkenones, and

7 crenarchaeol cannot be made within any single sediment horizon from these data, it appears that

8 crenarchaeol has an intermediate age that falls between the (old) alkenones and the (young) fatty

9 acids (Mollenhauer et al., 2003; Mollenhauer et al., 2007). This implies that GDGTs in the 10 Benguela Upwelling System have an intermediate degree of lability.

However, direct evidence about the degradation potential of GDGTs is limited, and previous assessments of the relative lability of GDGTs have yielded contradictory results. 13 Sinninghe Damsté et al. (2002) compared abundances of alkenones, GDGTs, and other lipid biomarkers in sediment cores from three locations in the Arabian Sea. These cores were geographically proximal, but from different water column depths (920m, 1470m and 3001m). Presumably, all three cores experienced similar overlying surface water conditions and export production, but had varying bottom water oxygen concentrations. A comparison of alkenones and GDGTs in both anoxic and oxic samples showed greater preservation of alkenones in some cores and greater preservation of GDGTs in others (Sinninghe Damsté et al., 2002). These data suggested that both compound classes have similar resistance to degradation, although it also is

21 possible that downslope sediment transport could have affected the results. Alkenone and GDGT 22 preservation efficiencies $>100 \%$ indicate material was added to the $1470 \mathrm{~m}$ and $3001 \mathrm{~m}$ sites by advection of sediments (Sinninghe Damsté et al., 2002). A similar result was reported in a study 24 of organic-rich turbidite sediments from the Madeira Abyssal Plain (Huguet, 2007). In most instances, the $\mathrm{C}_{37}$ alkenone preservation efficiency was slightly higher than the preservation efficiencies of individual archaeal GDGTs. However, there were exceptions where the alkenone 27 preservation efficiency was slightly lower than GDGT preservation efficiency and one instance 
1 where it was much higher. These results may again suggest comparable lability between

2 alkenones and GDGTs, although both cases are affected by an undetermined amount of exposure

3 to oxygen while on the continental shelf. These results are not compatible with radiocarbon data

4 discussed above and are not easily explained.

$5 \quad$ Mollenhauer et al. (2007) have shown that alkenones and GDGTs are re-suspended from 6 sediments and transported across the Namibian continental shelf. During this process, GDGTs are degraded more quickly than alkenones and GDGTs increasingly reflect a local surface export source while alkenones are a combination of local and laterally advected material. These results are more compatible with our radiocarbon data, although may be inconsistent with the results based on concentration data alone (Sinninghe Damsté et al., 2002; Huguet, 2007).

Assessing the degradation of alkenones and GDGTs in sinking particulate organic matter (POM) within the water column is complicated by the fact that GDGT production is not limited to surface waters. However, mesopelagic archaea generally are thought to be free-living 14 (DeLong et al., 1993; Woebken et al., 2007), and most evidence suggests that sediment traps selectively accumulate archaeal biomass associated with POM sinking from the surface of the GDGT flux survives transport from 1500m to 3000m (Wuchter et al., 2006) compared to 55-65\% preservation of alkenone flux between approximately the same depths (Wakeham et al., 2002). These data also suggest that GDGTs are preferentially degraded relative to alkenones when degradation specifically is occurring in an oxic water column. interpretation. TEX $_{86}$-calculated temperatures (Figure 5) have a similar general pattern as the 24 SSTs derived from foraminiferal $\delta^{18} \mathrm{O}$ values (Keigwin, 1996). Although our values are offset with a bias towards warmer SSTs (by approximately $2^{\circ} \mathrm{C}$ ), they mirror the foraminiferal temperatures much more accurately than do the alkenone temperatures from these horizons. The $27 \mathrm{U}_{37}^{\mathrm{K}^{\prime}}$ temperatures support the interpretation of a fractional contribution of alkenones from colder 
1 waters (Ohkouchi et al., 2002), while our results suggest that both GDGTs and planktonic

2 foraminifera have primarily local sources. This is consistent with a contribution of alkenones but

3 not of GDGTs within the fine-grained fraction that arrives from the Canadian Margin. Such a

4 hypothesis also would predict that the largest differences between the $\Delta^{14} \mathrm{C}$ values of alkenones

5 and GDGTs should correspond with the largest differences between the $\mathrm{U}_{37}^{\mathrm{K}^{\prime}}$ and $\mathrm{TEX}_{86}$

6 temperature reconstructions. Our data agree, showing a weak relationship within a wide degree

7 of scatter that suggests this is not the only factor affecting the accumulation of GDGTs.

8 In summary, three lines of evidence - radiocarbon values, sediment trap studies, and

9 temperature reconstructions - support preferential degradation of GDGTs compared to alkenones

10 under oxic conditions. However, results from sediment cores (Sinninghe Damsté et al., 2002;

11 Huguet, 2007) in some cases may be contradictory. Regardless, the apparent differential lability

12 cannot explain how GDGTs can become more ${ }^{14} \mathrm{C}$-depleted than associated alkenones.

\subsubsection{Contribution of GDGTs exported from deep in the water column}

Crenarchaeota are found at all depths in the marine water column (e.g., Karner et al., 2001; Herndl et al., 2005). They primarily are believed to be autotrophs (Wuchter et al., 2003; Herndl et al., 2005; Könneke et al., 2005), and $\Delta^{14} \mathrm{C}$ values of their GDGTs closely parallel the ${ }^{14} \mathrm{C}$ content of DIC (Pearson et al., 2001; Ingalls et al., 2006). Because the ${ }^{14} \mathrm{C}$ content of DIC

20 decreases with depth, GDGTs produced by archaea in the deep water column are more ${ }^{14} \mathrm{C}$ -

21 depleted relative to GDGTs produced in surface waters (Ingalls et al., 2006). This process could

22 deliver anomalously old GDGTs to sediments and potentially could explain how $\Delta^{14} \mathrm{C}$ values of 23 GDGTs in some cases are more negative than values from corresponding alkenones.

Mechanistically, however, this is a difficult hypothesis to reconcile. Export from the sea surface, where grazing incorporates lipids into sinking POC, is supported by particulate flux studies and by $\mathrm{TEX}_{86}$ temperature reconstructions (e.g., Schouten et al., 2002; Wuchter et al.,

27 2006). A similarly efficient packaging and transport mechanism for export of GDGTs from the 
deeper water column has not been identified, and sub-surface export of GDGTs is not expected to contribute significantly to the sedimentary GDGT pool in most locations.

However, evidence suggests that such an unidentified mechanism could exist. In a recent study of GDGT fluxes in Santa Barbara Basin, Huguet et al. (2007) concluded that the TEX 86 temperature recorded in a deep-water sediment trap $\left(\mathrm{TEX}_{86}\right.$ temperatures $\left.8-12^{\circ} \mathrm{C}\right)$ reflected a GDGT lipid flux from variable depths below $75 \mathrm{~m}$ rather than from the surface $\left(12-21^{\circ} \mathrm{C}\right)$. This was interpreted in terms of a single depth of export production that intermittently shoaled and deepened (Huguet et al., 2007). These results could equally be interpreted, however, as reflecting an integrated signal exported from a large but variable fraction of the entire water column.

To explore the potential magnitude of sub-surface export, we used a two end-member model. It treats sedimentary GDGTs as a mixture of material derived from two sources: the water column and a pre-aged source. The latter could be interpreted as lateral advection of sedimentary GDGTs, local benthic production, or a combination of these sources. The $\Delta^{14} \mathrm{C}$ value of the water column fraction reflects DIC at the modeled depth(s) of export, and the $\Delta^{14} \mathrm{C}$ value and fractional contribution of the pre-aged source is assumed to be constant with time. Total sedimentary GDGTs therefore would be represented by:

$$
\Delta_{\mathrm{GDGT}}=\mathrm{f}^{*} \Delta_{\text {water column }}+(1-\mathrm{f}) * \Delta_{\text {pre-aged }}
$$

where $f$ is the fraction of the sedimentary GDGT pool derived from the water column. Both $f$ and $\Delta_{\text {pre-aged }}$ are unknown, but this equation can be solved for pre-bomb and post-bomb conditions. This allows determination of both unknowns.

Two cases were examined: (i) export of GDGTs from the surface ocean (0-75m) and (ii) export of GDGTs from below $75 \mathrm{~m}$ in the water column. Input parameters are summarized in Table 3. Decay-corrected values of $\Delta{ }^{14} \mathrm{C}$ from planktonic foraminifera define the local ${ }^{14} \mathrm{C}$ content of surface water DIC in both post-bomb and pre-bomb conditions $\left(\Delta_{\text {water-column }}\right.$, case $(i)$, Table 3; Pearson et al., 2000). The post-bomb and pre-bomb $\Delta^{14} \mathrm{C}$ profiles of DIC below $75 \mathrm{~m}$ in the water column were estimated from the WOCE profile for station 10 of line P17C (Tsuchiya, 2000; Table 3). For case (ii), an equal abundance of GDGTs was assumed to be exported from 
1 all depths $>75 \mathrm{~m}$, and a depth-integrated average $\Delta^{14} \mathrm{C}$ value was calculated from the DIC profile

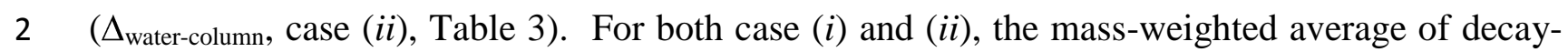

3 corrected $\Delta^{14} \mathrm{C}$ measurements was used for $\Delta_{\mathrm{GDGT}}$.

Solving the mass balance for case $(i)$ allows between $0-26 \%$ of GDGTs to derive from surface waters $(0-75 \mathrm{~m})$. The remainder would derive from the pre-aged (advective or benthic) source, which would have an average $\Delta^{14} \mathrm{C}$ value of $-122 \%$. In the case of uniform export from

7 below $75 \mathrm{~m}$ depth (case (ii)), the values of $\Delta^{14} \mathrm{C}$ for the deep water column and for the measured

8 sedimentary GDGTs are so similar that up to $100 \%$ of the GDGTs in the sediment could come

9 from $75-900 \mathrm{~m}$ in the water column $(f=0.51 \pm 0.5)$. The separate pre-aged source, if there is one, would have an average $\Delta^{14} \mathrm{C}$ value of $-107 \%$. It is not possible to distinguish which is the correct option in case (ii), but it is evident that if GDGT export flux derives entirely from the surface (case (i)), then nearly all of the GDGTs in SMB sediments are either detrital or from production in the sediments. This is supported by the absence of an observable bombradiocarbon signal in GDGTs from 0-2.5 cm in Santa Monica Basin sediment, in agreement with previous results (Pearson et al., 2001). And in both cases, the $\Delta^{14} \mathrm{C}$ value of the pre-aged component is remarkably similar to the $\Delta^{14} \mathrm{C}$ content of deep basin DIC.

Based on these mass-balance calculations, GDGT export from surface waters and from deeper in the water column both appear possible; but in either case, contemporary surface water cannot be the source of the vast majority of sedimenting GDGTs. This process distinguishes temperatures at this location.

\subsubsection{Contribution of GDGTs from sedimentary archaea}

Active communities containing both Euryarchaeota and Crenarchaeota are found in 27 continental margin (e.g., Vetriani et al., 1998; Inagaki et al., 2003; Sørensen and Teske, 2006) 
1 and deep sea sediments (e.g., Vetriani et al., 1999; Teske, 2006). These assemblages are a

2 potential source of pre-aged GDGTs, as they could directly (by heterotrophs and methanogens)

3 or indirectly (by methanotrophs or autotrophs) utilize aged sedimentary organic matter to

4 produce membrane lipids.

GDGTs at Bermuda Rise have minimal contributions from anomalously old sources, either sedimentary or advected. However, ${ }^{14} \mathrm{C}$-depleted GDGTs are required in Santa Monica Basin and may not be exclusively sourced to the deep water column. Another possible explanation is benthic archaeal production. Bermuda Rise sediments are carbonate-rich and organic-poor. The anoxic, richly organic environment of Santa Monica Basin sediments may in contrast support a more productive archaeal community and therefore a larger source of GDGTs produced in situ. A higher abundance of archaeal cells is found in sediments of the Peru Margin compared with the more poorly-organic sediments of the Peru Basin and Equatorial Pacific (Inagaki et al., 2006; Teske, 2006), and archaeal biomass scales with total organic carbon content (Lipp et al., submitted).

To date, there appear to be no studies of the microbial community structure of Santa Monica Basin sediments. Evidence for occasional release of methane into the water column (Ward and Kilpatrick, 1993) does suggest that Euryarchaeota inhabit these sediments at depth. Although methanogenic and methanotrophic archaeal cells can be detected in non-methanogenic continental margin sediments (e.g., Inagaki et al., 2003; Parkes et al., 2007), the unculturable Miscellaneous Crenarchaeotal Group (MCG), South African Goldmine Euryarchaeotal Group 1 (SAGMEG-1), and the Euryarchaeotal Marine Benthic Group D (MBGD) are generally abundant near the surface of organic-rich sediments (Inagaki et al., 2003; Sørensen and Teske, 2006; Teske, 2006). These phylogenetic groups likely also dominate the assemblages of shallow Santa Monica Basin sediments. The extent to which this assumed archaeal assemblage would contribute ${ }^{14} \mathrm{C}$-depleted GDGTs depends, in part, on the profile of membrane lipids that it produces. 
Both Crenarchaeota and Euryarchaeota produce GDGTs (e.g. Koga and Morii, 2005; Schouten et al., 2007a). Although cultured strains that can synthesize tetraether compounds other than GDGT-0 appear to be limited (summarized in Schouten et al., 2007a), production of GDGTs $0-3$ by assemblages of sedimentary methanotrophic archaea has been noted (Pancost et al., 2001; Schouten et al., 2003; Zhang et al., 2003; Bouloubassi et al., 2005; Werne and Sinninghe Damsté, 2005; Oba et al., 2006). Production of all GDGTs by mixed crenarchaeotal and euryarchaeotal communities was indicated in Peru Margin sediments (Biddle et al., 2006) and has elsewhere been shown to be abundant (Lipp et al., submitted). Meters deep into these sediments, GDGTs with attached diglycosidic polar head groups are assumed to be synthesized in situ by active cells, and these intact GDGTs have $\delta^{13} \mathrm{C}$ values that appear to reflect incorporation of organic matter rather than methane. Similar sediment-dwelling archaea in Santa Monica Basin might contribute pre-aged GDGTs, if their carbon substrate is suitably ${ }^{14} \mathrm{C}$ depleted.

While there may be some methane cycling in Santa Monica Basin, the $\delta^{13} \mathrm{C}$ values of the GDGTs indicate that the majority of all GDGTs are likely to be made by autotrophic or heterotrophic archaea. The average $\delta^{13} \mathrm{C}$ value of GDGTs in Santa Monica Basin $(-19.4 \pm 0.9 \%$ ) is slightly lower than in Bermuda Rise sediments $(-18.6 \pm 0.6 \%$ ), although the degree of variability may make this difference insignificant. All evidence suggests that archaeal GDGTs in Bermuda Rise predominantly originate in the water column. Therefore they probably reflect autotrophic Crenarchaeota and display a constant fractionation relative to DIC. This would result in relatively constant $\delta^{13} \mathrm{C}$ values. The GDGTs in Santa Monica Basin could reflect mixed sources from autotrophic production in the water column and synthesis from organic substrates or ${ }^{13} \mathrm{C}$-depleted DIC in the sediment. Assuming sedimentary archaea produce GDGTs with a $\delta^{13} \mathrm{C}$ value of $-22 \%$ (average between $\delta^{13} \mathrm{C}$ values measured by FISH-SIMS and on biphytane derivatives of intact polar lipids (Biddle et al., 2006)) and GDGTs are exported from the water column with a $\delta^{13} \mathrm{C}$ value equal to average water column GDGTs (-19\%), $\sim 0-30 \%$ of total GDGTs in SMB could derive from heterotrophic production. This estimate is highly uncertain, 
1 however, given the small range and high uncertainty of the endmember $\delta^{13} \mathrm{C}$ values. Regardless,

2 a $30 \%$ source from benthic production is not enough to explain the degree of ${ }^{14} \mathrm{C}$-depletion

3 observed in Santa Monica Basin GDGTs, unless the planktonic fraction also comes primarily

4 from the deeper (>75m) water column (section 5.1.2), and thus both benthic production and

5 deep-water export could be important.

Values of $\mathrm{TEX}_{86}$ also are highly variable in Santa Monica Basin sediments, ranging from

70.49 to $0.77\left(17^{\circ} \mathrm{C}\right.$ to $\left.32^{\circ} \mathrm{C}\right)$. These values are anomalously warm and highly variable.

8 Overlying sea surface temperatures range from $14^{\circ} \mathrm{C}$ to $19^{\circ} \mathrm{C}$ annually (California Cooperative

9 Oceanic Fisheries Investigations (CalCOFI) database). $\mathrm{TEX}_{86}$ values calculated from suspended

10 particulate matter collected at $25 \mathrm{~m}, 100 \mathrm{~m}, 600 \mathrm{~m}$, and $850 \mathrm{~m}$ in the water column also span this

11 temperature range $\left(\mathrm{TEX}_{86}=0.42-0.53\right.$ or $13^{\circ} \mathrm{C}$ to $19^{\circ} \mathrm{C}$; Wuchter et al., 2005; Kim et al., 2008).

12 The POM data derive from a combination of suspended and sinking archaeal biomass, 13 presumably including deep water column archaea, and yet cannot explain anomalous 14 temperatures in excess of $30^{\circ} \mathrm{C}$. This suggests that at least some fraction of sedimentary GDGTs 15 must indeed reflect marine benthic archaeal production in situ.

In subsurface sediments from the Peru Margin, the heterotrophic archaeal assemblage produces more GDGT-0 than any other GDGT; only a small amount of crenarchaeol is produced (Biddle et al., 2006). We find tentative evidence for a similar pattern in Santa Monica Basin sediments, where a small decrease in the relative abundance of crenarchaeol with depth is offset by a small increase in the relative abundance of GDGT-0 (Table EA2-1). Although there is some variability in the abundances of GDGTs in Bermuda Rise, no similar trend with depth was detected (Table EA2-1). We also find that GDGTs 0-3 show depletion in ${ }^{14} \mathrm{C}$ with depth relative to the ${ }^{14} \mathrm{C}$ content of crenarchaeol, and these differences are too large to be explained by radiocarbon decay over this short time (Table 1). GDGT-0 and GDGTs $1-3$ have the most ${ }^{14} \mathrm{C}$ enriched values near the surface, where they would be expected to have the smallest contribution

26 from sedimentary production, but are more depleted in ${ }^{14} \mathrm{C}$ than crenarchaeol at all depths below $270.75 \mathrm{~cm}$. In addition, the $\delta^{13} \mathrm{C}$ values of crenarchaeol and GDGTs $1-3$ are constant with depth, 
1 averaging $-19.0 \pm 0.1 \%$, but the $\delta^{13} \mathrm{C}$ value of GDGT-0 decreases with depth from $-18.4 \%$ to

$2-21.4 \%$. The trends we observe in values of $\delta^{13} \mathrm{C}$ and $\Delta^{14} \mathrm{C}$ with depth would be consistent with 3 significant in situ production of GDGT-0, and possibly GDGTs 1-3.

\subsubsection{Contribution of GDGTs from terrestrial sources}

6

Terrestrial material remains a final option to explain the ${ }^{14} \mathrm{C}$ anomalies among the GDGTs. Terrestrially-derived $n$-alkanes and long-chain fatty acids have been detected in Santa Monica Basin (Pearson and Eglinton, 2000; Mollenhauer and Eglinton, 2007). Hwang et al. (2005) also observed that lipids are a significant fraction of the organic material delivered to the California Margin by riverine POM. Sediments of the Bermuda Rise show evidence of terrigenous input based on the abundance of clay and silt particles (Keigwin, 1996). This terrestrial material is thought to come from aeolian inputs from North America and Africa, local resuspended sediments eroded from the Bermuda Rise scarp, and more distantly from resuspended terrigenous sediment from the Canadian Margin off Nova Scotia (Keigwin, 2006).

A large recent survey of globally-distributed soils found archaeal GDGTs detectable in nearly all samples (Weijers et al., 2007, Weijers et al., 2006). GDGTs also recently have been reported in river water (Herfort et al., 2006). This ubiquitous presence of GDGTs in continental material indicates that they may be an important component of terrigenous organic carbon, where they could become pre-aged by intermediate storage in continental reservoirs. Although the concentration of GDGTs in soils is up to two orders of magnitude lower than in marine sediments (Weijers et al., 2006), terrigenous GDGTs that are not degraded during transport to the ocean are more likely to be physically protected (e.g., associated with mineral surfaces) and less susceptible to degradation than autochthonous GDGTs exported from the surface ocean (Huguet, 2007). This input would cause the marine sedimentary GDGT pool to appear more aged.

BIT index values (Hopmans et al., 2004) were calculated to determine the influence of terrestrially derived GDGTs within the sedimentary organic matter of both Santa Monica Basin 
and Bermuda Rise (Table EA2-1). These values do not indicate a large terrestrial contribution of tetraethers. There is a small relative abundance of bacterial tetraethers at all depths in Bermuda Rise sediment (average BIT value is 0.12), which suggests that marine-derived material is predominant. Although branched tetraethers were only measured in one sediment horizon from Santa Monica Basin, the BIT index value (0.15) again does not indicate significant input of terrigenous GDGTs. Furthermore, there does not appear to be any relationship between the BIT index values and the magnitude of the difference between $\Delta{ }^{14} \mathrm{C}_{\mathrm{GDGTs}}$ and $\Delta{ }^{14} \mathrm{C}_{\text {foraminifera }}$ (Table 1 , Table EA2-1). We conclude that in these environments, pre-aged GDGTs from terrestrial sources are unlikely to explain ${ }^{14} \mathrm{C}$-depleted values of GDGTs.

\subsection{Crenarchaeol regioisomer and $\mathrm{TEX}_{86}$}

2

Because of its small relative abundance, it was only possible to make two individual measurements of the ${ }^{14} \mathrm{C}$ content of crenarchaeol regioisomer. However, these two samples show that this GDGT has a source or history that is different from the rest of the GDGT assemblage. In each case, the $\Delta^{14} \mathrm{C}$ value is significantly more negative than other GDGTs from the same sediment depth: it is $159 \%$ depleted relative to the abundance-weighted average of other co-occurring GDGTs at 0.75-1.5 $\mathrm{cm}$ and 219\%o depleted at 1.5-2.5 cm.

These unusual values are not likely to result from contamination or isotopic fractionation. Any contamination occurring during the process of sample preparation would have affected all GDGTs rather than just the crenarchaeol regioisomer, and this was not observed. The addition of exogenous carbon by the GDGT extraction and isolation process has been carefully quantified (Shah and Pearson, 2007) and corrected for by isotope mass balance with full propagation of error (Experimental section and Electronic Annex EA-1). This process of blank correction has also been successfully applied to much smaller samples in which any contaminant would have caused a proportionally greater bias (e.g., all GDGTs from 32-34 cm in Santa Monica Basin and all data reported in Ingalls et al. (2006)). Fractionation also cannot explain these offsets, as the 
1 value of $\delta^{13} \mathrm{C}$ measured for crenarchaeol regioisomer $(-20.6 \%)$ is similar to other measured

2 GDGTs. Finally, by definition, values of $\Delta^{14} \mathrm{C}$ already are corrected for biosynthetic isotope 3 fractionation.

The distinctively depleted ${ }^{14} \mathrm{C}$ content of crenarchaeol regioisomer is difficult to explain.

5 Its value of $\delta^{13} \mathrm{C}$ is not low enough to implicate sedimentary methane oxidizers. Although it is 6 thought to be exported from the surface ocean (Schouten et al., 2002), it has been reported that 7 crenarchaeol regioisomer is almost undetectable in the surface waters of the Black Sea 8 (Wakeham et al., 2004) and North Central Pacific (Ingalls et al., 2006) and is not present in the 9 cultured species, Nitrosopumilus maritimus (Schouten et al., 2008). In addition, marine crenarchaeal communities enriched from North Sea and Indian Ocean surface water produced minimal crenarchaeol regioisomer in incubation studies: its abundance was a factor of 14 lower than found in typical sediments (Wuchter et al., 2004; Schouten et al., 2007b).

Alternatively, it could be possible that the regioisomer is produced by isomerization of crenarchaeol during diagenesis or has a separate (benthic) biosynthetic source. Either option might accumulate greater relative quantities of crenarchaeol regioisomer in sediments of increasing age, however, and no such increase with depth is observed in either Bermuda Rise or Santa Monica Basin. Its proportion is relatively constant, although relative enrichment of the regioisomer within a particular endmember component (i.e., the benthic-derived fraction) cannot be conclusively ruled out. Another possibility is that the crenarchaeol regioisomer is particularly resistant to degradation. GDGT concentrations measured in oxic and anoxic layers of Madeira sediment sources and/or isomerization during diagenesis, possibly combined with advection from distant locations. If so, these processes could affect crenarchaeol regioisomer throughout

27 oceanic sediments. Further work is needed to investigate this possibility. 
An aged or non-surficial source for crenarchaeol regioisomer has implications for

2 paleotemperature reconstructions. Previous work empirically establishes the $\mathrm{TEX}_{86}$ index as a

3 robust signal for sea surface temperature (e.g., Schouten et al., 2002; Wuchter et al., 2005;

4 Wuchter et al., 2006), likely reflecting a biophysical adaptation (Wuchter et al., 2004; Schouten

5 et al., 2007b). Archaea are known to increase the number of rings in their membrane lipids in

6 response to increasing growth temperature (e.g., DeRosa and Gambacorta, 1988; Uda et al.,

7 2001). In developing the $\mathrm{TEX}_{86}$ index, Schouten et al. (2002) noted that a formula incorporating

8 four of the six abundant GDGTs in sediments, namely GDGTs 1-3 and the crenarchaeol

9 regioisomer, resulted in the best correlation with annual mean sea surface temperature. Given

10 the ${ }^{14} \mathrm{C}$ results above, the question becomes how is the anomalous crenarchaeol regioisomer

11 accommodated within this relationship? Its isotopic composition suggests a different origin.

TEX $_{86}$ is constructed as a ratio of GDGT abundances:

$$
\mathrm{TEX}_{86}=\frac{[\text { GDGT-2]+[GDGT-3]+ [crenarchaeol regioisomer }]}{[\text { GDGT-1]+[GDGT-2]+[GDGT-3]+[crenarchaeol regioisomer }]}
$$

With increasing temperature (i.e., increasing $\mathrm{TEX}_{86}$ value), the GDGT with one internal

17 cyclopentane ring (GDGT-1) should have a smaller relative abundance compared to each individual GDGT with more rings, as well as to their sum, based on the proposed biophysical mechanism. For example, Sluijs et al. (2006) created a modified formula, TEX' ${ }_{86}$, from which GDGT-3 was removed. This changes the absolute value of TEX' ${ }_{86}$ relative to $\mathrm{TEX}_{86}$, but it does not appreciably change the overall slope of the TEX-temperature relationship. This allows

22 paleotemperature to be calculated from $\mathrm{TEX}^{\prime}{ }_{86}$ with similar precision as from $\mathrm{TEX}_{86}$.

For comparison, we constructed an additional modified version of the $\mathrm{TEX}_{86}$ index, 24 removing the contribution of crenarchaeol regioisomer $\left(\mathrm{TEX}^{*}{ }_{86}\right)$. $\mathrm{TEX}^{*} 86$ is calculated from:

$$
\mathrm{TEX}^{*}{ }_{86}=\frac{[\mathrm{GDGT}-2]+[\mathrm{GDGT}-3]}{[\mathrm{GDGT}-1]+[\mathrm{GDGT}-2]+[\mathrm{GDGT}-3]}
$$


Similar to $\mathrm{TEX}^{\prime}{ }_{86}$, removing crenarchaeol regioisomer should not significantly change the slope

2 of the modified $\mathrm{TEX}_{86}$ relationship if the relationship between GDGT-1 and crenarchaeol

3 regioisomer is analogous to the relationship between GDGT-1 and GDGT-3.

The relationships of $\mathrm{TEX}_{86}{ }_{86}$ and $\mathrm{TEX}^{*}{ }_{86}$ to the original $\mathrm{TEX}_{86}$ index are illustrated in Figures $6 \mathrm{a}$ and $6 \mathrm{~b}$. The three index values are calculated for our Bermuda Rise and Santa Monica Basin samples as well as for the only published study of sedimentary lipids with reported

7 GDGT abundances (Herfort et al., 2006). The values of the modified $\mathrm{TEX}_{86}$ formulae are plotted

8 against values of the original $\mathrm{TEX}_{86}$ formula. Removal of GDGT-3 from TEX 86 changes the

9 absolute value of the index, shown by the constant offset between $\mathrm{TEX}^{\prime}{ }_{86}$ and $\mathrm{TEX}_{86}$ (Figure

10 6a), at a constant slope of approximately one (Figure 6a). The role of GDGT-3 (like GDGT-1

11 and GDGT-2) in the $\mathrm{TEX}_{86}$ index follows the pattern predicted by the biophysical mechanism

12 requiring more internal rings at higher temperatures.

The crenarchaeol regioisomer, in contrast, appears to have a different role in creating the

$14 \mathrm{TEX}_{86}$ correlation with temperature. $\mathrm{TEX}^{*}{ }_{86}$ values are offset from $\mathrm{TEX}_{86}$ values by a variable 15 amount (slope $=0.69$, Figure 6b). The larger offset at higher values of $\mathrm{TEX}_{86}$ shows that the 16 presence of crenarchaeol regioisomer in the original $\mathrm{TEX}_{86}$ formula is responsible for 17 maintaining a steep slope, and therefore a greater sensitivity to temperature (i.e., $18 \Delta \mathrm{TEX}_{86} / \Delta$ temperature is greater for $\mathrm{TEX}_{86}$ than for $\left.\mathrm{TEX}_{86} *\right)$. This certainly controls the 19 precision with which sea surface temperatures can be reconstructed. controlled differently from GDGTs $1-3$, and the ${ }^{14} \mathrm{C}$ data indicate that a process other than recent 22 export from the sea surface affects the concentration of crenarchaeol regioisomer in sediments. 23 Finding an explanation for this ${ }^{14} \mathrm{C}$ anomaly and determining how crenarchaeol regioisomer is 24 regulated by temperature will be essential in future studies. 


\section{CONCLUSIONS}

2

Our radiocarbon measurements show that there are similarities and differences between the post-depositional processes that affect alkenones and GDGTs. Both may be affected by resuspension from the sediment and advective transport. However, GDGTs do not appear to survive transport as well as do alkenones. Under conditions of oxic degradation within the water column, especially, evidence suggests that GDGTs are more labile and alkenones more resistant. This suggests that sedimentary alkenones are more adversely susceptible to artifacts when constructing paleo-SST records; GDGTs are more likely to be of local origin.

Conversely, it appears that sedimentary GDGT signatures more often may be subject to influences originating from below the photic zone. There may be export of GDGTs from archaea that live deeply in the water column. It also appears that deep export may not necessarily explain all of the ${ }^{14} \mathrm{C}$-aged GDGTs found in Santa Monica Basin. Although deep production in the water column likely contributes some GDGTs, this source may not be depleted enough in ${ }^{14} \mathrm{C}$ to account for the signal observed in sediments, especially in the cases of crenarchaeol regioisomer and GDGT-0. Thus, in systems such as Santa Monica Basin there also may be a sedimentary source of anomalously old GDGTs that are produced in situ. This effect may be observed in environments that are organic rich and/or that have anoxic bottom waters or sediments and/or poor reconstructed values of temperature derived from $\mathrm{TEX}_{86}$. There does not appear to be significant terrestrial input of GDGTs either to Bermuda Rise or to Santa Monica Basin, but this should be examined in more detail in Santa Monica Basin, as only one value of the BIT index could be calculated.

One GDGT, the crenarchaeol regioisomer, appears to have a source that is different from the other five GDGTs. Its $\Delta^{14} \mathrm{C}$ value was significantly more negative than other co-occurring GDGTs, and investigation of its contribution to the $\mathrm{TEX}_{86}$ index also supports an alternative origin or control on its abundance. The true source of this GDGT is unknown, but upper water column samples and archaeal cultures contain minimal or no crenarchaeol regioisomer. 
1 Understanding how and/or if these processes affect $\mathrm{TEX}_{86}$ paleotemperature reconstructions will 2 be an important avenue of further investigation.

Finally, this work shows that there are multiple processes affecting the abundance and

4 preservation of sedimentary GDGTs. The importance of each of these processes will vary

5 according to local seafloor topography, oxygenation conditions, and sedimentary archaeal

6 communities. A better understanding of these processes and their variability between locations

7 will inform TEX $_{86}$-derived SST reconstructions and lead to a better understanding of the sources

8 and fates of sedimentary GDGTs.

9 
2 We thank NOSAMS, W. J. Jenkins, A. P. McNichol, and L. Xu for collaboration on sample 3 dilutions and for partial support of radiocarbon analyses. We thank S. Carter for laboratory 4 assistance. We are grateful to Stuart Wakeham, Rienk Smittenberg, and Carme Huguet for their 5 extensive and helpful reviews. This work was supported by the David \& Lucille Packard $6 \quad$ Foundation and by NSF-OCE-0241363 and EAR-0311937 (to A.P.). 7 
Biddle J. F., Lipp J. S., Lever M. A., Lloyd K. G., Sørensen K. B., Anderson R., Fredricks H. F.,

3 Elvert M., Kelly T. J., Schrag D. P., Sogin M. L., Brenchley J. E., Teske A., House C. H. and Hinrichs K. U. (2006) Heterotrophic Archaea dominate sedimentary subsurface ecosystems off Peru. Proc. Natl. Acad. Sci. USA 103, 3846-3851.

Brassell S. C., Eglinton G., Marlowe I. T., Pflaumann U. and Sarnthein M. (1986) Molecular stratigraphy - a new tool for climatic assessment. Nature 320, 129-133.

Bouloubassi I., Aloisi G., Pancost R. D., Hopmans E. C., Pierre C. and Sinninghe Damsté J. S. (2006) Archaeal and bacterial lipids in authigenic carbonate crusts from eastern Mediterranean mud volcanoes. Org. Geochem. 37, 484-500.

Çağatay M. N., Borowski W. S. and Ternois Y. G. (2001) Factors affecting the diagenesis of Quaternary sediments at ODP Leg 172 sites in western North Atlantic: evidence from pore water and sediment geochemistry. Chem. Geol. 175, 467-484.

Christensen C. J., Gorsline D. S., Hammond D. E. and Lund S. P. (1996) Nonannual laminations and expansion of anoxic basin-floor conditions in Santa-Monica Basin, California Borderland, over the past 4 centuries. Mar. Geol. 116, 399-418.

Conte M. H., Sicre M.-A., Rühlemann C., Weber J. C., Schulte S., Schulz-Bull D. and Blanz T. (2006) Global temperature calibration of the alkenone unsaturation index UK'37 in surface waters and comparison with surface sediments. Geochem. Geophys. Geosyst. 7, Q02005. doi: $10.1029 / 2005 G C 001054$.

DeLong E. F. (1992) Archaea in coastal marine environments. Proc. Natl. Acad. Sci. USA 89, 5685-5689.

DeRosa M. and Gambacorta A. (1988) The lipids of archaebacteria. Prog. Lipid Res. 27, 153175.

Fuhrman J., McCallum, A. and Davis, A. (1992) Novel major archaebacterial group from marine plankton. Nature 356, 148-149.

Grimalt J. O., Rullkötter J., Sicre M.-A., Summons R., Farrington J., Harvey H. R., Goñi M. and Sawada K. (2000) Modifications of the $\mathrm{C}_{37}$ alkenone and alkenoate composition in the water 
column and sediment: Possible implications for sea surface temperature estimates in paleoceanography. Geochem. Geophys. Geosystems 1, 2000.GC000053.

Hagadorn J. W., Stott L. D., Sinha A. and Rincon M. (1995) Geochemical and sedimentologic variations in inter-annually laminated sediments from Santa-Monica Basin. Mar. Geol. 125, $111-131$

Herfort L., Schouten S., Boon J. P. and Sinninghe Damsté J. S. (2006) Application of the TEX 86 temperature proxy to the southern North Sea. Org. Geochem. 37, 1715-1726.

Herndl G. J., Reinthaler T., Teira E., van Aken, H., Veth C., Pernthaler A. and Pernthaler J. (2005) Contribution of Archaea to total prokaryotic production in the deep Atlantic Ocean. Appl. Environ. Microbiol. 71, 2303-2309.

Hopmans E. C., Weijers J. W. H., Schefuß E., Herfort L., Sinninghe Damsté J. S. and Schouten S. (2004) A novel proxy for terrestrial organic matter in sediments based on branched and isoprenoid tetraether lipids. Earth. Planet. Sci. Lett. 224, 107-116.

Huguet C. (2007) TEX 86 paleothermometry: proxy validation and application in marine sediments. Ph. D. Thesis, Royal Netherlands Institute for Sea Research.

Huguet C., Schimmelmann A., Thunell R., Lourens L. J., Sinninghe Damsté J. S. and Schouten S. (2007) A study of the $\mathrm{TEX}_{86}$ paleothermometer in the water column and sediments of the Santa Barbara Basin, California. Paleoceanography 22, 10.1029/2006PA001310.

Hwang J., Druffel E. R. M. and Komada T. (2005) Transport of organic carbon from the California coast to the slope region: A study of specific $\Delta^{14} \mathrm{C}$ and $\delta^{13} \mathrm{C}$ signatures of organic compound classes. Global Biogeochem. Cycles 19, 10.1029/2004GB002422.

Inagaki F., Nunoura T., Nakagawa S., Teske A., Lever M., Lauer A., Suzuki M., Takai K., Delwiche M., Colwell F. S., Nealson K. H., Horikoshi K., D’Hondt S. and Jørgensen B. B. (2006) Biogeographical distribution and diversity of microbes in methane hydrate-bearing deep marine sediments on the Pacific Ocean Margin. Proc. Natl. Acad. Sci. USA 103, 2815-2820. Inagaki F., Suzuki M., Takai K., Oida H., Sakamoto T., Aoki K., Nealson K. H. and Horikoshi K. (2003) Microbial communities associated with geological horizons in coastal subseafloor sediments from the Sea of Okhotsk. Appl. Environ. Microbiol. 69, 7224-7235. 
Ingalls A. E., Shah S. R., Hansman R. L., Aluwihare L. I., Santos G. M., Druffel E. R. M. and Pearson A. (2006) Quantifying archaeal community autotrophy in the mesopelagic ocean using natural radiocarbon. Proc. Natl. Acad. Sci. USA 103, 6442-6447.

Karner M. B., DeLong E. F. and Karl D. M. (2001) Archaeal dominance in the mesopelagic zone of the Pacific Ocean. Nature 409, 507-510.

Keigwin L. D. (1996) The Little Ice Age and Medieval warm period in the Sargasso Sea. Science 274, 1504-1508.

Kim J. H., Schouten S., Hopmans E.C., Donner B. and Sinninghe Damsté J. S. (2008) Global sediment core-top calibration of the $\mathrm{TEX}_{86}$ paleothermometer in the ocean. Geochim. Cosmochim. Acta 72, 1154-1173.

Koga Y. and Morii H. (2005) Recent advances in structural research on ether lipids from archaea including comparative and physiological aspect. Biosci., Biotechnol., Biochem. 69, 2019-2034.

Könneke M., Bernhard A. E., de la Torre J., Walker C. B., Waterbury J. B. and Stahl D. A. (2005) Isolation of an autotrophic ammonia-oxidizing marine archaeon. Nature 437, 534-546.

Kuypers M. M. M., Blokker P., Erbacher J., Kinkel H., Pancost R. D., Schouten S. and Sinninghe Damsté J. S. (2002) Archaeal remains dominate marine organic matter from the early Albian oceanic anoxic event 1b. Palaeogeogr., Palaeoclimateol., Palaeoecol. 185, 211 234.

Marlowe I. T., Green J. C., Neal A. C., Brassell S. C., Eglinton G. and Course P. A. (1984) Long-chain (n- $\left.\mathrm{C}_{37}-\mathrm{C}_{39}\right)$ alkenones in the prymnesiophyceae - distribution of alkenones and other lipids and their taxonomic significance. Br. Phycol. J. 19, 203-216.

Mollenhauer G. and Eglinton T. I. (2007) Diagenetic and sedimentological controls on the composition of organic matter preserved in California Borderland Basin sediments. Limnol. Oceanogr. 52, 558-576.

Mollenhauer G., Eglinton T. I., Ohkouchi N., Schneider R. R., Müller P. J., Grootes P. M. and Rullkötter J. (2003) Asynchronous alkenone and foraminifera records from the Benguela Upwelling System. Geochim. Cosmochim. Acta 67, 2157-2171.

Mollenhauer G., Kienast M., Lamy F., Meggers H., Schneider R. R., Hayes J. M. and Eglinton T. I. (2005) An evaluation of C-14 age relationships between co-occurring foraminifera, 
alkenones, and total organic carbon in continental margin sediments. Paleoceanography $\mathbf{2 0}$, 10.1029/2004PA001103.

Mollenhauer G., Inthorn M., Vogt T., Zabel M., Sinninghe Damsté J. S. and Eglinton T. I. (2007) Aging of marine organic matter during cross-shelf lateral transport in the Benguela upwelling system revealed by compound-specific radiocarbon dating. Geochem. Geophys. Geosystems $\mathbf{8}$, 10.1029/2007GC001603.

Oba M., Sakata S. and Tsunogai U. (2006) Polar and neutral isopranyl glycerol ether lipids as biomarkers of archaea in near-surface sediments from the Nankai Trough. Org. Geochem. 37, 1643-1654.

Ohkouchi N., Eglinton T. I., Keigwin L. D. and Hayes J. M. (2002) Spatial and temporal offsets between proxy records in a sediment drift. Science 298, 1224-1227.

Ohkouchi N., Xu L., Reddy C. M., Montluçon D. and Eglinton T. I. (2005) Radiocarbon dating of alkenones from marine sediments: I. Isolation protocol. Radiocarbon 47, 401-412.

Ohkouchi N., Montluçon D. and Eglinton T. I. The geochemical anatomy of a deep-sea sediment drift (Bermuda Rise, NW Atlantic). Submitted to Deep Sea Research.

Pancost R. D., Hopmans E. C., Sinninghe Damsté J. S. and the MEDINAUT Shipboard Scientific Party. (2001) Archaeal lipids in Mediterranean cold seeps: Molecular proxies for anaerobic methane oxidation. Geochim. Cosmochim. Acta 65, 1611-1627.

Parkes R. J., Cragg B. A., Banning N., Brock F., Webster G., Fry J. C., Hornibrook E., Pancost R. D., Kelly S., Knab N., Jørgensen B. B., Rinna J. and Weightman A. J. (2007)

Biogeochemistry and biodiversity of methane cycling in subsurface marine sediments (Skagerrak, Denmark). Environ. Microbiol. 9, 1146-1161.

Pearson A. and Eglinton T.I. (2000) The origin of $n$-alkanes in Santa Monica Basin surface sediment: a model based on compound-specific $\Delta^{14} \mathrm{C}$ and $\delta^{13} \mathrm{C}$ data. Org. Geochem. 31, 11031116.

Pearson A., McNichol A. P., Schneider R. J., Von Reden K. F. and Zheng Y. (1998) Microscale AMS ${ }^{14} \mathrm{C}$ measurement at NOSAMS. Radiocarbon 40, 61-75.

Pearson, A., Eglinton T. I. and McNichol A.P. (2000) An organic tracer for surface ocean radiocarbon. Paleoceanography 15, 541-550. 
Pearson A., McNichol A. P., Benitez-Nelson B. C., Hayes J. M. and Eglinton T. I. (2001)

Origins of lipid biomarkers in Santa Monica Basin surface sediment: A case study using compound-specific $\Delta^{14} \mathrm{C}$ analysis. Geochim. Cosmochim. Acta 65, 3123-3137.

Sachs, J. P. and Lehman S. J. (1999) Subtropical North Atlantic temperatures 60,000 to 30,000

5 years ago. Science 286, 756-759.

Schouten S., Hopmans E. C., Schefu $\beta$ E. and Sinninghe Damsté J. S. (2002) Distributional variations in marine crenarchaeotal membrane lipids: a new tool for reconstructing ancient sea water temperatures? Earth. Planet. Sci. Lett. 204, 265-274.

Schouten S., Hopmans E. C., Forster A., van Breugel Y., Kuypers M. M. M. and Sinninghe Damsté J. S. (2003) Extremely high sea-surface temperatures at low latitudes during the middle Cretaceous as revealed by archaeal membrane lipids. Geology 31, 1069-1072.

Schouten S., Wakeham S. G., Hopmans E. C. and Sinninghe Damsté J. S. (2003)

Biogeochemical evidence that thermophilic archaea mediate the anaerobic oxidation of methane. Appl. Environ. Microbiol. 69, 1680-1686.

Schouten S., Hopmans E. C. and Sinninghe Damsté J. S. (2004) The effect of maturity and depositional redox conditions on archaeal tetraether lipid palaeothermometry. Org. Geochem. 35, 567-571.

Schouten S., van der Meer M. T. J., Hopmans E. C., Rijpstra W. I. C., Reysenbach A. L., Ward D. M. and Sinninghe Damsté J. S. (2007a) Archaeal and bacterial glycerol dialkyl glycerol tetraether lipids in hot springs of Yellowstone National Park. Appl. Environ. Microbiol. 73, 6181-6191.

Schouten S., Forster A., Panoto E. and Sinninghe Damsté J. S. (2007b) Towards calibration of the $\mathrm{TEX}_{86}$ paleothermometer for tropical sea surface temperatures in ancient greenhouse worlds. Org. Geochem. 38, 1537-1546.

Shah S. R. and Pearson A. (2007) Ultra-microscale (5-25 $\mu \mathrm{g} \mathrm{C}$ ) analysis of individual lipids by ${ }^{14} \mathrm{C}$ AMS: Assessment and correction for sample processing blanks. Radiocarbon 49, 69-82. Sinninghe Damsté J. S., Rijpstra W. I. C. and Reichart G. J. (2002) The influence of oxic degradation on the sedimentary biomarker record II. Evidence from Arabian Sea sediments. Geochim. Cosmochim. Acta 66, 2737-2754. 
Sinninghe Damsté J. S., Schouten S., Hopmans E. C., van Duin A. C. T. and Geenevasen J. A. J. (2002) Crenarchaeol: the characteristic core glycerol dibiphytanyl glycerol tetraether membrane lipid of cosmopolitan pelagic crenarchaeota. J. Lipid Res. 43, 1641-1651.

Sluijs A., Schouten S., Pagani M., Woltering M., Brinkhuis H., Sinninghe Damsté J. S., Dickens G. R., Huber M., Reichart G. J., Stein R., Matthiessen J., Lourens L. J., Pedentchouk N., Backman J. and Moran K. (2006) Subtropical arctic ocean temperatures during the Palaeocene/Eocene thermal maximum. Nature 441, 610-613.

Smittenberg R. H., Hopmans E. C., Schouten S. and Sinninghe Damsté J. S. (2002) Rapid isolation of biomarkers for compound specific radiocarbon dating using high-performance liquid chromatography and flow injection analysis-atmospheric pressure chemical ionization mass spectrometry. J. Chromatogr. A 978, 129-140.

Sorensen K. B. and Teske A. (2006) Stratified communities of active archaea in deep marine subsurface sediments. Appl. Environ. Microbiol. 72, 4596-4603.

Stuiver M. and Polach H. A. (1977) Discussion, reporting of ${ }^{14} \mathrm{C}$ data. Radiocarbon 19, 355-363. Teske A.P. (2006) Microbial communities of deep marine subsurface sediments: Molecular and cultivation surveys. Geomicrobiol. J. 23, 357-368.

Teske A., Hinrichs K. U., Edgcomb V., Gomez A. D., Kysela D., Sylva S. P., Sogin M. L. and Jannasch H. W. (2002) Microbial diversity of hydrothermal sediments in the Guaymas Basin: Evidence for anaerobic methanotrophic communities. Appl. Environ. Microbiol. 68, 19942007.

Tsuchiya M. (2000) World Ocean Circulation Experiment hydrographic public data, Line P17C. http://whpo.ucsd.edu/data/onetime/pacific/p17/p17c/index.htm.

Uda I., Sugai A., Itoh Y. H. and Itoh T. (2001) Variation in molecular species of polar lipids from Thermoplasma acidophilum depends on growth temperature. Lipids 36, 103-105. Vetriani C., Reysenbach A. L. and Dore J. (1998) Recovery and phylogenetic analysis of archaeal rRNA sequences from continental shelf sediments. FEMS Microbiol. Lett. 161, 83-88. Vetriani C., Jannasch H. W., MacGregor B. J., Stahl D. A. and Reysenbach A. L. (1999) Population structure and phylogenetic characterization of marine benthic archaea in deep-sea sediments. Appl. Environ. Microbiol. 65, 4375-4384. 
Wakeham S. G., Lewis C. M., Hopmans E. C., Schouten S. and Sinninghe Damsté J. S. (2003) Archaea mediate anaerobic oxidation of methane in deep euxinic waters of the Black Sea.

3 Geochim. Cosmochim. Acta 67, 1359-1374.

Wakeham S. G., Hopmans E. C., Schouten S. and Sinninghe Damsté J. S. (2004) Archaeal lipids

5 and anaerobic oxidation of methane in euxinic water columns: a comparative study of the Black Sea and Cariaco Basin. Chem. Geol. 205, 427-442.

Ward B. B. and Kilpatrick K. A. (1993) Methane oxidation associated with mid-depth methane maxima in the Southern California Bight. Cont. Shelf Res. 13, 1111-1122.

Weijers J. W. H, Schouten S., Spaargaren O. C. and Sinninghe Damsté J. S. (2006) Occurrence and distribution of tetraether membrane lipids in soils: Implications for the use of the $\mathrm{TEX}_{86}$ proxy and the BIT index. Org. Geochem. 37, 1680-1693.

Weijers J. W. H, Schouten S., van den Donker J. C., Hopmans E. C. and Sinninghe Damsté J. S. (2007) Environmental controls on bacterial tetraether membrane lipid distribution in soils. Geochim. Cosmochim. Acta 71, 703-713.

Werne J.P. and Sinninghe Damsté J. S. (2005) Mixed sources contribute to the molecular isotopic signature of methane-rich mud breccia sediments of Kazan mud volcano (eastern Mediterranean). Org. Geochem. 36, 13-27.

Woebken D., Fuchs B. A., Kuypers M. M. M., Amann R. (2007) Potential interactions of particle-associated annamox bacteria and archaeal partners in the Namibian upwelling system. Appl. Environ. Microbiol. 73, 4648-4657.

Wuchter C., Schouten S., Boschker H. T. S., and Sinninghe Damsté J. S. (2003) Bicarbonate uptake by marine Crenarchaeota. FEMS Microbiol. Lett. 219, 203-207.

Wuchter C., Schouten S., Coolen M. J. L. and Sinninghe Damsté J. S. (2004) Temperaturedependent variation in the distribution of tetraether membrane lipids of marine Crenarchaeota: Implications for $\mathrm{TEX}_{86}$ paleothermometry. Paleoceanography 19, 10.1029/2004PA001041. Wuchter C., Schouten S., Wakeham S. G. and Sinninghe Damsté J. S. (2005) Temporal and spatial variation in tetraether membrane lipids of marine Crenarchaeota in particulate organic matter: Implications for $\mathrm{TEX}_{86}$ paleothermometry. Paleoceanography 20, 10.1029/2004PA001110. 
1 Wuchter C., Schouten S., Wakeham S. G. and Sinninghe Damsté J. S. (2006) Archaeal tetraether 2 membrane lipid fluxes in the northeastern Pacific and the Arabian Sea: Implications for TEX 86 3 paleothermometry. Paleoceanography 21, 10.1029/2006PA001279.

4 Zhang C. L., Pancost R. D., Sassen R., Qian Y. and Macko S. A. (2003) Archaeal lipid

5 biomarkers and isotopic evidence of anaerobic methane oxidation associated with gas hydrates $6 \quad$ in the Gulf of Mexico. Org. Geochem. 34, 827-836. 


\section{TABLES}

Table 1. $\delta^{13} \mathrm{C}$ and $\Delta{ }^{14} \mathrm{C}$ values of GDGTs from Bermuda Rise and Santa Monica Basin

\begin{tabular}{|c|c|c|c|c|c|c|c|}
\hline Location & Core & $\begin{array}{c}\text { Sediment } \\
\text { Depth }(\mathrm{cm})\end{array}$ & GDGTs in sample & $\begin{array}{c}\text { Sample } \\
\text { Size }(\mu \mathrm{gC})\end{array}$ & $\begin{array}{l}\delta^{13} \mathrm{C} \\
(\% \circ)\end{array}$ & $\begin{array}{l}\Delta^{14} \mathrm{C} \\
(\% \circ)\end{array}$ & $\begin{array}{c}\Delta^{14} \mathrm{C} \\
\pm \\
\end{array}$ \\
\hline \multirow[t]{21}{*}{ Bermuda Rise } & $\mathrm{BC} 9 \mathrm{C}$ & $0-1$ & All & 3 & \multicolumn{3}{|c|}{ insufficient carbon } \\
\hline & BC9C & $1-2$ & All & 41 & -19.4 & -163 & 16 \\
\hline & $\mathrm{BC} 9 \mathrm{C}$ & $3-4$ & All & 76 & -18.5 & -228 & 12 \\
\hline & BC9C & $4-6$ & All & 51 & -18.5 & -146 & 15 \\
\hline & BC9 & $6-7$ & GDGTs 0-3 & 31 & & -121 & 18 \\
\hline & BC9 & $6-7$ & crenarchaeol \& isomer & 50 & -18.1 & -140 & 20 \\
\hline & BC9 & $9-11$ & GDGTs $0-3$ & 46 & -18.2 & -125 & 11 \\
\hline & BC9 & $9-11$ & crenarchaeol \& isomer & 33 & & -117 & 17 \\
\hline & BC9 & $21-23$ & GDGTs 0-3 & 61 & -18.3 & -223 & 11 \\
\hline & BC9 & $21-23$ & crenarchaeol \& isomer & 41 & -18.5 & -215 & 15 \\
\hline & GGC5 & $192-206$ & GDGTs 0-3 & 84 & -18.2 & -837 & 6 \\
\hline & GGC5 & $282-292$ & GDGTs 0-3 & 40 & & -852 & 11 \\
\hline & GGC5 & $282-292$ & crenarchaeol \& isomer & 85 & -17.9 & -863 & 5 \\
\hline & GGC5 & $350-360$ & GDGTs 0-3 & 30 & & -866 & 14 \\
\hline & GGC5 & $350-360$ & crenarchaeol \& isomer & 68 & -18.5 & -870 & 6 \\
\hline & GGC5 & $360-372$ & All & 55 & -19.7 & -866 & 8 \\
\hline & GPC5 & $345-355$ & All & 33 & -18.8 & -848 & 11 \\
\hline & GPC5 & $907-912$ & GDGTs 0-3 & 33 & & -909 & 11 \\
\hline & GPC5 & $907-912$ & crenarchaeol \& isomer & 49 & -19.0 & -894 & 8 \\
\hline & GPC5 & $1244-1260$ & GDGTs 0-3 & 102 & -19.6 & -928 & 6 \\
\hline & GPC5 & $1244-1260$ & crenarchaeol \& isomer & 87 & -18.5 & -929 & 6 \\
\hline \multirow[t]{16}{*}{ Santa Monica Basin } & Pulse-32 & $0-0.75$ & All & & \multicolumn{3}{|c|}{ insufficient carbon } \\
\hline & Pulse-32 & $0.75-1.5$ & GDGT-0 & 134 & -18.4 & -67 & 7 \\
\hline & Pulse-32 & $0.75-1.5$ & GDGTs 1-3 & 69 & -19.1 & -77 & 10 \\
\hline & Pulse-32 & $0.75-1.5$ & crenarchaeol & 219 & & -91 & 22 \\
\hline & Pulse-32 & $0.75-1.5$ & crenarchaeol Isomer & 20 & -20.6 & -241 & 19 \\
\hline & Pulse-32 & $1.5-2.5$ & GDGT-0 & 173 & -19.2 & -111 & 9 \\
\hline & Pulse-32 & $1.5-2.5$ & GDGTs 1-3 & 73 & -18.9 & -106 & 10 \\
\hline & Pulse-32 & $1.5-2.5$ & crenarchaeol & 131 & -19.0 & -98 & 9 \\
\hline & Pulse-32 & $1.5-2.5$ & crenarchaeol Isomer & 25 & & -323 & 20 \\
\hline & Pulse-32 & $2.5-3.5$ & GDGT-0 & 27 & -19.8 & -116 & 13 \\
\hline & Pulse-32 & $2.5-3.5$ & GDGTs 1-3 & 70 & -18.8 & -108 & 7 \\
\hline & Pulse-32 & $2.5-3.5$ & crenarchaeol & 86 & & -88 & 9 \\
\hline & SMB-900 & $6-7$ & GDGTs 1-3 & 69 & -19.0 & -161 & 9 \\
\hline & SMB-900 & $32-34$ & GDGT-0 & 6 & -21.4 & -350 & 75 \\
\hline & SMB-900 & $32-34$ & GDGTs 1-3 & 9 & & -370 & 93 \\
\hline & SMB-900 & $32-34$ & crenarchaeol & 15 & & -321 & 31 \\
\hline
\end{tabular}


Table 2. Summary of $\Delta^{14} \mathrm{C}$ values calculated from previous results and measured in this study

\begin{tabular}{|c|c|c|c|c|c|c|c|c|c|c|c|c|}
\hline \multirow{2}{*}{\multicolumn{2}{|c|}{$\begin{array}{cc}\text { Core } & \begin{array}{c}\text { Sediment } \\
\text { Depth }(\mathrm{cm})\end{array} \\
\text { Santa Monica Basin } \\
\end{array}$}} & \multicolumn{11}{|c|}{$\Delta^{14} \mathrm{C}(\%)$} \\
\hline & & \multicolumn{2}{|c|}{$\begin{array}{c}\text { planktonic } \\
\text { foraminifera }\end{array}$} & \multicolumn{2}{|c|}{$\begin{array}{c}\text { benthic } \\
\text { foraminifera }\end{array}$} & \multicolumn{2}{|l|}{ Alkenone } & \multirow{2}{*}{$\frac{\text { GDGT-0 }}{-67 \pm 7}$} & \multirow{2}{*}{$\begin{array}{l}\text { GDGTs } \\
1-3 \\
-77 \pm 10\end{array}$} & \multirow{2}{*}{$\frac{\text { Crenarchaeol } \mathrm{Cr}}{-91 \pm 22}$} & \multirow{2}{*}{$\frac{\text { crenarchaeol isomer }}{-241 \pm 19}$} & \multirow{2}{*}{$\begin{array}{c}\text { abundance-weighted } \\
\text { GDGT average } \\
-93\end{array}$} \\
\hline Pulse-32 & $0.75-1.5$ & $64 \pm 4$ & a & $-188 \pm 6$ & a & $12 \pm 5$ & & & & & & \\
\hline Pulse-32 & $1.5-2.5$ & $81 \pm 6$ & a & $-194 \pm 3$ & a & & & $-111 \pm 9$ & $-106 \pm 10$ & $-98 \pm 9$ & $-323 \pm 20$ & -114 \\
\hline Pulse-32 & $2.5-3.5$ & $-68 \pm 4$ & a & $-189 \pm 4$ & a & $-105 \pm 4$ & & $-116 \pm 13$ & $-108 \pm 7$ & $-88 \pm 9$ & & -90 \\
\hline SMB-900 & $6-7$ & $-93 \pm 4$ & $\mathrm{~b}$ & & & $-124 \pm 7$ & $\mathrm{~b}$ & & $-161 \pm 9$ & & & \\
\hline SMB-900 & $32-34$ & & & & & $-363 \pm 16$ & $\mathrm{~b}$ & $-350 \pm 75$ & $-370 \pm 93$ & $-321 \pm 31$ & & -325 \\
\hline \multicolumn{2}{|c|}{ Bermuda Rise } & \multicolumn{2}{|c|}{$\begin{array}{l}\text { planktonic } \\
\text { foraminifera }\end{array}$} & & & Alkenone & & GDGTs 0-3 & & $\begin{array}{c}\text { crenarchaeol + } \\
\text { crenarchaeol Isomer }\end{array}$ & all GDGTs & $\begin{array}{c}\text { abundance-weighted } \\
\text { GDGT average }\end{array}$ \\
\hline $\mathrm{BC} 9 \mathrm{C}$ & $1-2$ & $-66 \pm 3$ & c & & & $-471 \pm 12$ & c & & & & $-163 \pm 16$ & -163 \\
\hline $\mathrm{BC} 9 \mathrm{C}$ & $3-4$ & $-93 \pm 4$ & c & & & & & & & & $-228 \pm 12$ & -228 \\
\hline $\mathrm{BC} 9 \mathrm{C}$ & $4-6$ & $-106 \pm 3$ & c & & & $-516 \pm 8$ & c & & & & $-146 \pm 15$ & -146 \\
\hline BC9 & $6-7$ & & & & & & & $-121 \pm 18$ & & $-140 \pm 20$ & & -128 \\
\hline BC9 & $9-11$ & $-139 \pm 3$ & c & & & $-324 \pm 8$ & c & $-125 \pm 11$ & & $-117 \pm 17$ & & -121 \\
\hline BC9 & $21-23$ & $-222 \pm 4$ & c & & & $-537 \pm 3$ & c & $-223 \pm 11$ & & $-215 \pm 15$ & & -219 \\
\hline GGC5 & $192-206$ & $-825 \pm 1$ & c & & & $-890 \pm 4$ & c & $-837 \pm 6$ & & & & \\
\hline GGC5 & $282-292$ & $-859 \pm 1$ & c & & & $-913 \pm 5$ & c & $-852 \pm 11$ & & $-863 \pm 5$ & & -857 \\
\hline GGC5 & $350-360$ & $-863 \pm 5$ & c & & & $-900 \pm 2$ & c & $-866 \pm 14$ & & $-870 \pm 6$ & & -868 \\
\hline GGC5 & $360-372$ & & & & & & & & & & $-866 \pm 8$ & -866 \\
\hline GPC5 & $345-355$ & $-829 \pm 1$ & c & & & & & & & & $-848 \pm 11$ & -848 \\
\hline GPC5 & $907-912$ & $-873 \pm 2$ & c & & & $-936 \pm 3$ & c & $-909 \pm 11$ & & $-894 \pm 8$ & & -901 \\
\hline GPC5 & $1244-1260$ & $-913 \pm 1$ & c & & & $-927 \pm 6$ & c & $-928 \pm 6$ & & $-929 \pm 6$ & & -929 \\
\hline
\end{tabular}

${ }^{a}$ calculated from decay-corrected $\Delta^{14} \mathrm{C}$ values reported in Pearson et al., 2000

${ }^{b}$ calculated from $\mathrm{f}_{\mathrm{MC}}$ reported in Mollenhauer et al., 2007

calculated from radiocarbon ages reported in Ohkouchi et al., 2002 
Table 3. Mixing model parameter values for surface (0-75m) and deep (75-900m) cases

\begin{tabular}{ccc}
\hline Parameter & post-bomb & pre-bomb \\
\hline $0-75 m \Delta_{\text {water column }}$ & $+63 \%$ a & $-81 \%$ \\
$75-900 m \Delta_{\text {water column }}{ }^{\text {b }}$ & $-89 \%$ o & $-120 \%$ \% \\
$\Delta_{\text {GDGTs }}$ & $-101 \pm 13 \%$ o & $-116 \pm 10 \%$ \\
\hline
\end{tabular}

\footnotetext{
${ }^{a}$ Post-bomb: depth-integrated average from DIC profile for WOCE station 10 line P17C. Prebomb values integrated from profile with upper $400 \mathrm{~m}$ values adjusted to reflect pre-bomb conditions.

${ }^{b}$ post-bomb and pre-bomb measurement error averaged to estimate uncertainty.
} 


\section{FIGURE CAPTIONS}

Figure 1. Molecular masses, designations and molecular structures of five of the six most abundant GDGTs in Santa Monica Basin and Bermuda Rise sediments. The crenarchaeol regioisomer is a regioisomer of crenarchaeol (Sinninghe Damsté, et al., 2002).

Figure 2. Summary of published radiocarbon measurements of alkenones vs. planktonic foraminifera, expressed as (a) values of $\Delta^{14} \mathrm{C}$ and (b) radiocarbon age. ${ }^{\mathrm{a}} \mathrm{Data}$ from Ohkouchi et al., 2002; $\Delta^{14} \mathrm{C}$ values calculated from reported radiocarbon ages assuming all measurements made in 2000. ${ }^{\mathrm{b}}$ Data from Mollenhauer and Eglinton, 2007 with two additional values reported in this study; $\Delta^{14} \mathrm{C}$ values calculated from reported fraction modern $\left(\mathrm{f}_{\mathrm{MC}}\right)$; and corresponding planktonic foraminiferal radiocarbon measurements calculated from decay-corrected $\Delta^{14} \mathrm{C}$ values reported in Pearson et al., 2000. ${ }^{\mathrm{c}}$ Data from Mollenhauer et al., 2003; $\Delta^{14} \mathrm{C}$ values calculated from reported percent modern ( $\mathrm{p}_{\mathrm{MC}}$ ) assuming all measurements made in $2001 .{ }^{\mathrm{d}}$ Data from Mollenhauer et al., 2005; $\Delta^{14} \mathrm{C}$ values calculated from reported $\mathrm{f}_{\mathrm{MC}}$ values assuming all measurements made in 2003.

Figure 3. (a) $\Delta^{14} \mathrm{C}$ values from Bermuda Rise. Filled circles represent measurements made on all six GDGTs combined. Measurements made on combined GDGT-0, GDGT-1, GDGT-2 and GDGT-3 are represented by filled squares. Combined measurements of crenarchaeol plus crenarchaeol regioisomer are represented by filled diamonds. ${ }^{a}$ Values of $\Delta^{14} \mathrm{C}$ for alkenones and foraminifera (G. ruber) from Ohkouchi et al. (2002). (b) $\Delta^{14} \mathrm{C}$ values from Santa Monica Basin. Measurements made on combined GDGT-1, GDGT-2 and GDGT-3 are represented by gray squares. Measurements of GDGT-0 (black squares), crenarchaeol (black diamonds), and crenarchaeol regioisomer (gray diamonds) were made on individual lipids. ${ }^{a}$ Values of $\Delta{ }^{14} \mathrm{C}$ for alkenones and mixed planktonic foraminifera for sediment depths 0-1, 6-7 and 32-34 cm from Mollenhauer et al. (2007; core SMB-900). The $\Delta^{14} \mathrm{C}$ values for GDGTs from depths 0-1, 6-7 and $32-34 \mathrm{~cm}$ also are from core SMB-900. The $\Delta^{14} \mathrm{C}$ values for .75-1.5, 1.5-2.5, 2.5-3.5, 3.5-4.5, 
and 4.5-5.5 cm are from Pulse-32 core, originally described in Pearson et al. (2000). $\Delta{ }^{14} \mathrm{C}$ values for planktonic (Neogloboquadrina spp.) and benthic (Bolivina spp.) foraminifera calculated from decay-corrected values reported in Pearson et al. (2000). Alkenone values for core Pulse-32 are from this study. Horizontal error bars are total ${ }^{14} \mathrm{C}$ measurement errors $(1 \sigma)$ and in most cases are smaller than the size of the symbols.

Figure 4. $\Delta^{14} \mathrm{C}$ values of alkenones and GDGTs vs. planktonic foraminifera for Bermuda Rise (a) and Santa Monica Basin (b). Individual GDGTs measurements from the same sediment depth are plotted separately; however replicate alkenone measurements (Mollenhauer and Eglinton, 2007) are averaged. Samples having values of $\Delta{ }^{14} C$ greater than $-84 \%$ contain bomb radiocarbon. Error bars represent $1 \sigma$ measurement uncertainties in $\Delta{ }^{14} \mathrm{C}$ values.

Figure 5. Paleotemperature proxy reconstructions for Bermuda Rise plotted against sediment age. Sea surface temperatures calculated from $\delta^{18} \mathrm{O}$ reported in Keigwin (1996), $U_{37}^{K \prime}$ values from Ohkouchi et al. (2002) converted to sea surface temperature using the most recent calibration of Conte et al. (2006) with an error of $1.2^{\circ} \mathrm{C}$. $\mathrm{TEX}_{86}$-temperature reconstructions calculated using calibration of Kim et al. (2008 with an error of $1.7^{\circ} \mathrm{C}$.

Figure 6. (a) TEX' ${ }_{86}$ calculated as described in Sluijs et al., 2006 (without GDGT-3); and (d) $\mathrm{TEX}_{86}$ (without crenarchaeol regioisomer). Modified formula TEX' ${ }_{86}$ and TEX* ${ }_{86}$ values were calculated for the Santa Monica Basin and Bermuda Rise samples reported here, as well as for values from the literature (North Sea sediments; Herfort et al., 2006). 


\section{FIGURES}

Figure 1

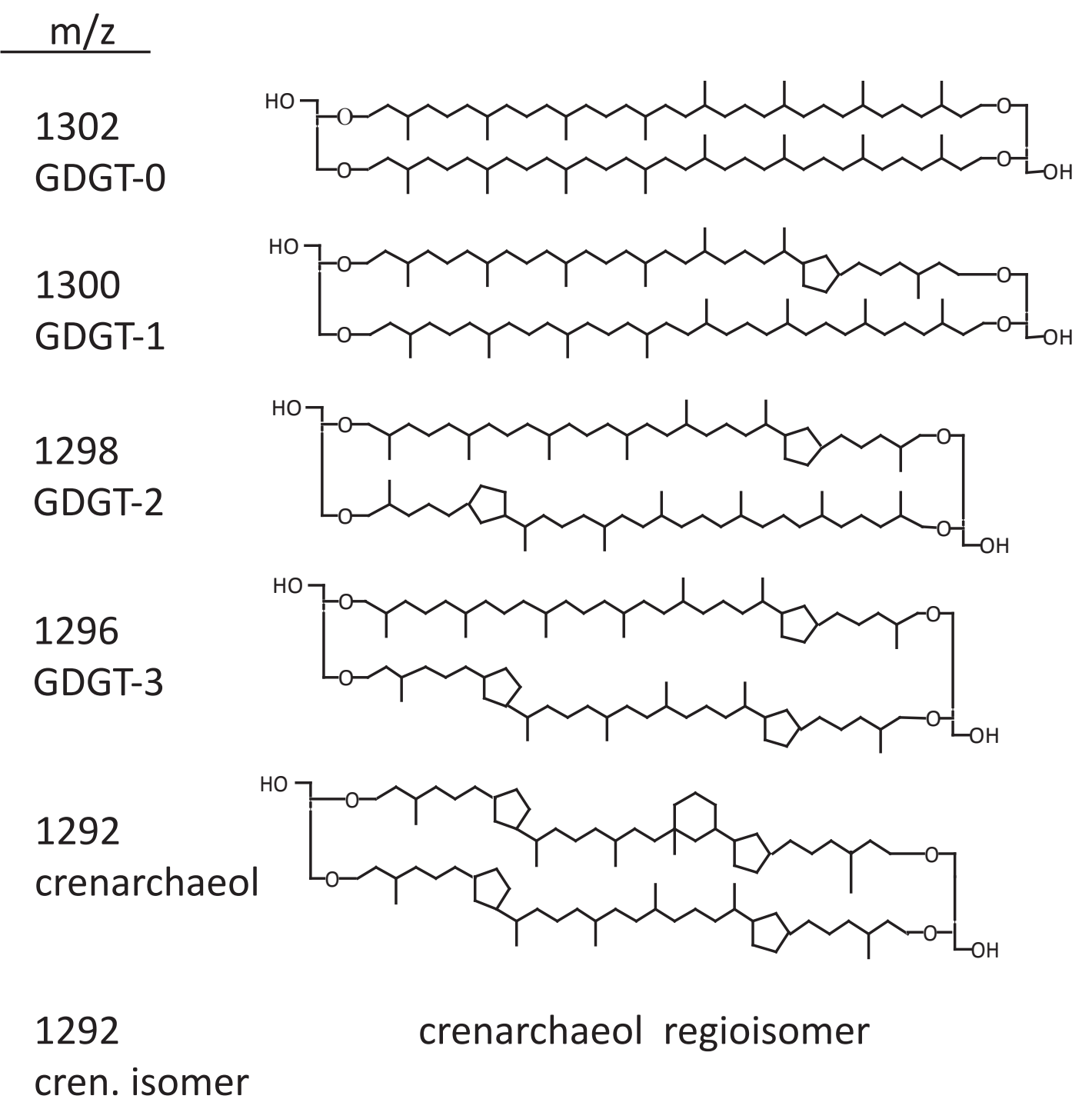


Figure 2
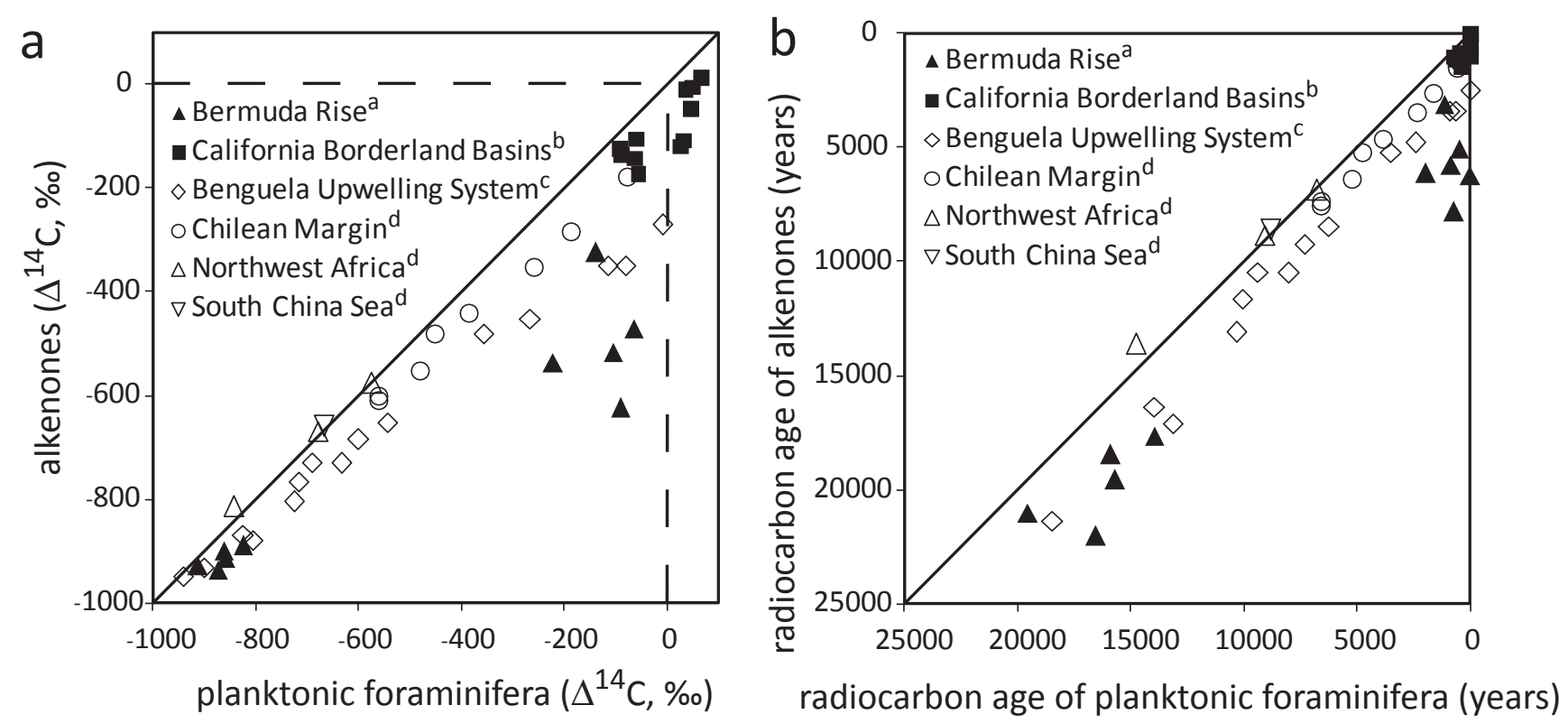


\section{Figure 3}
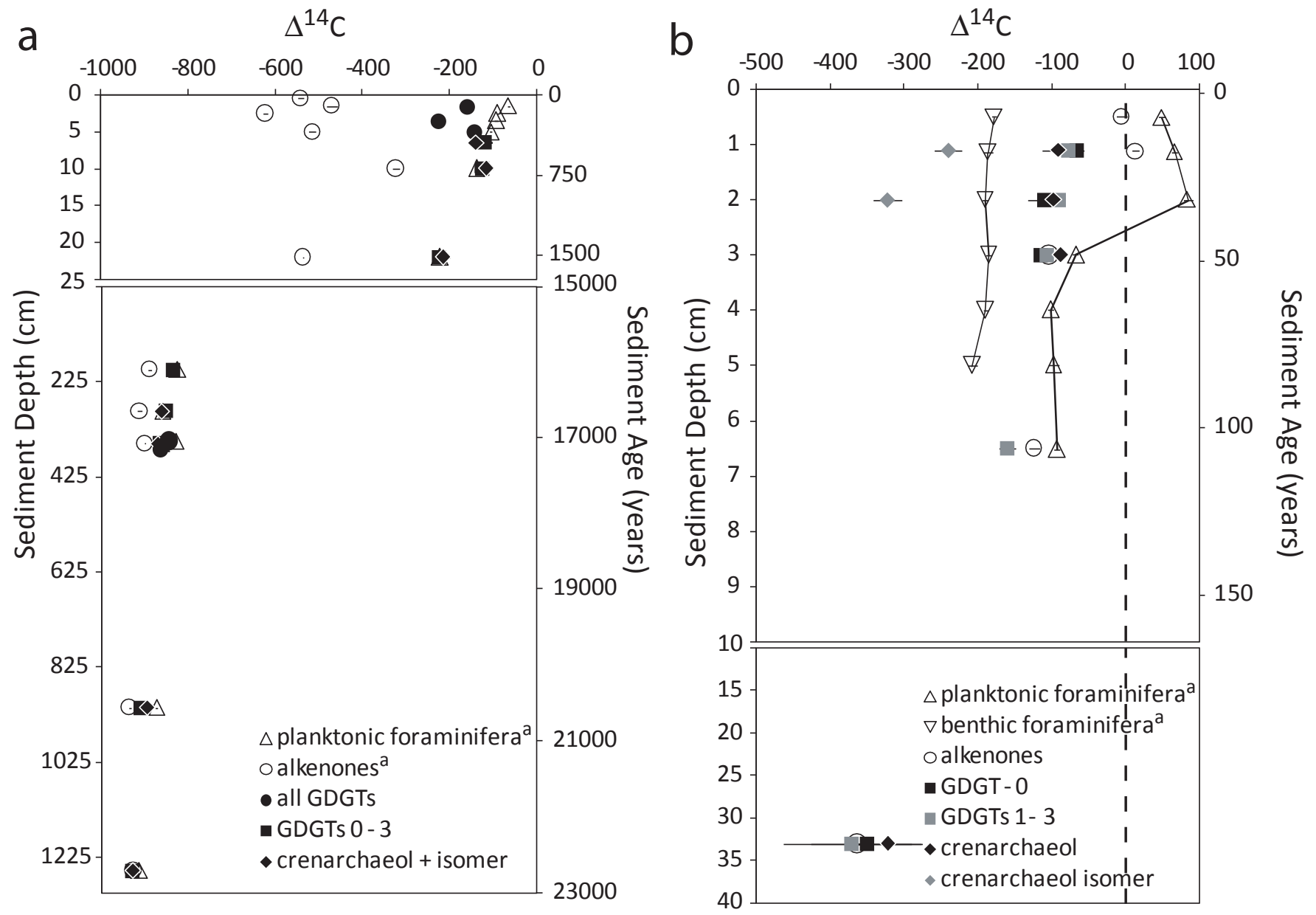


\section{Figure 4}
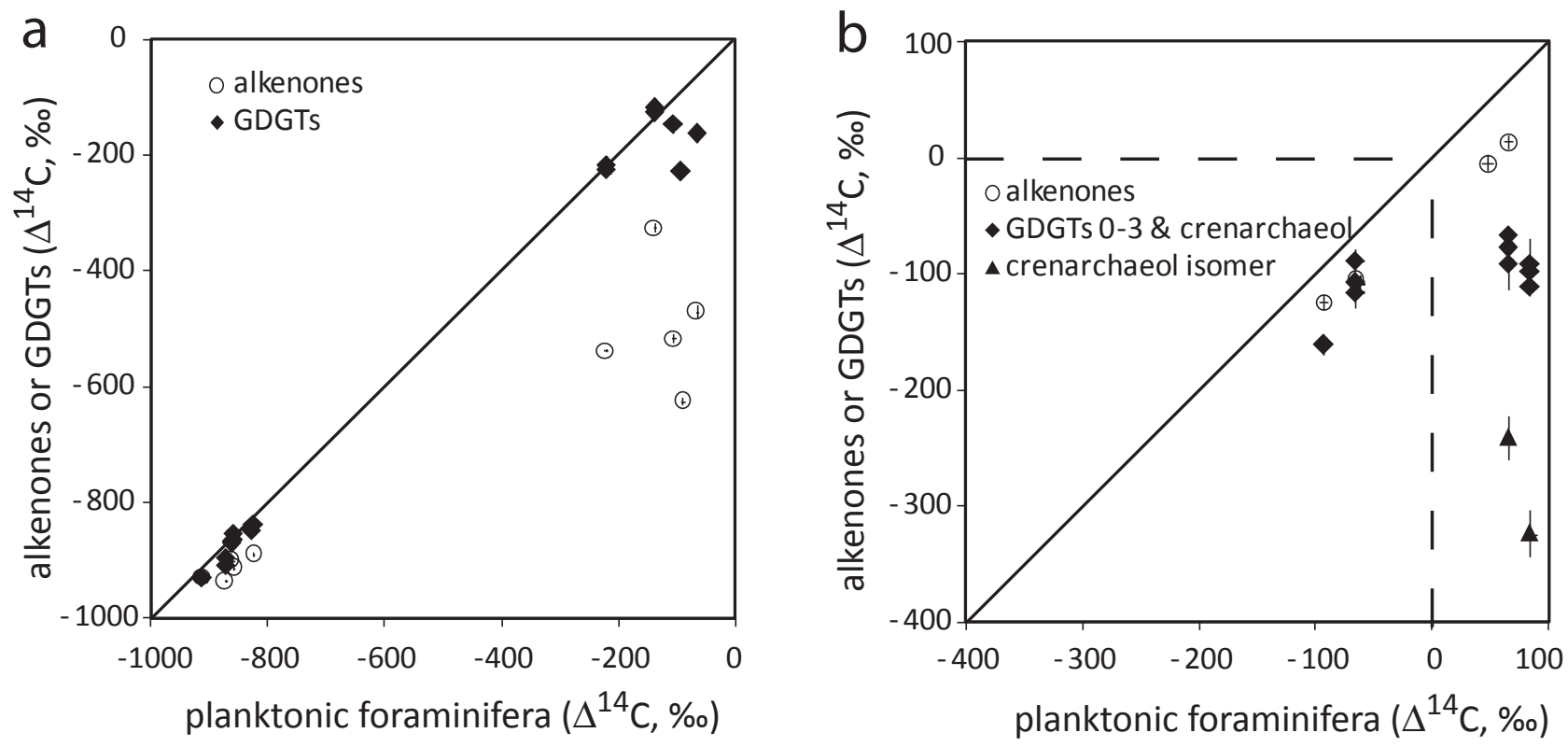
Figure 5

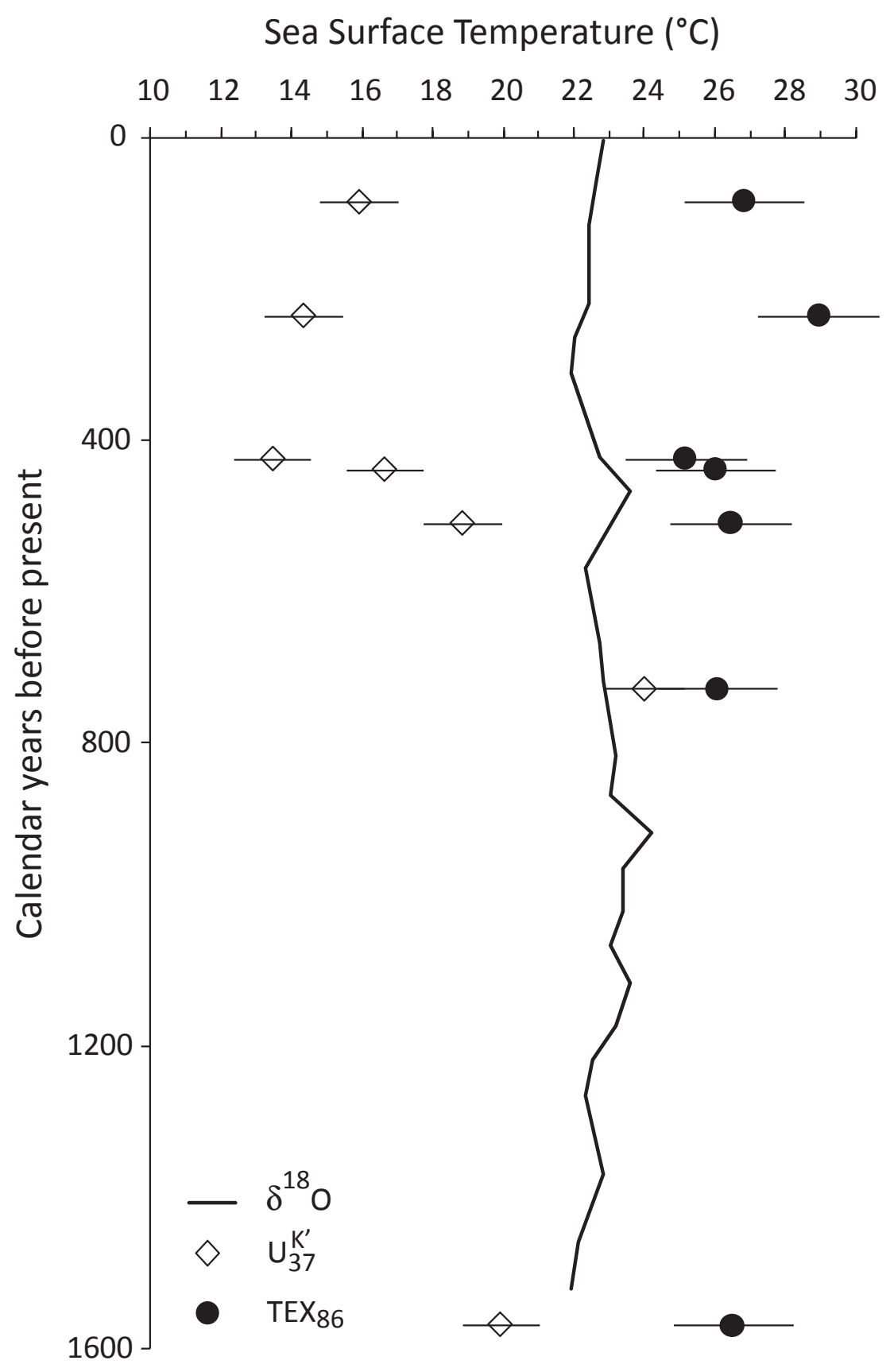


Figure 6
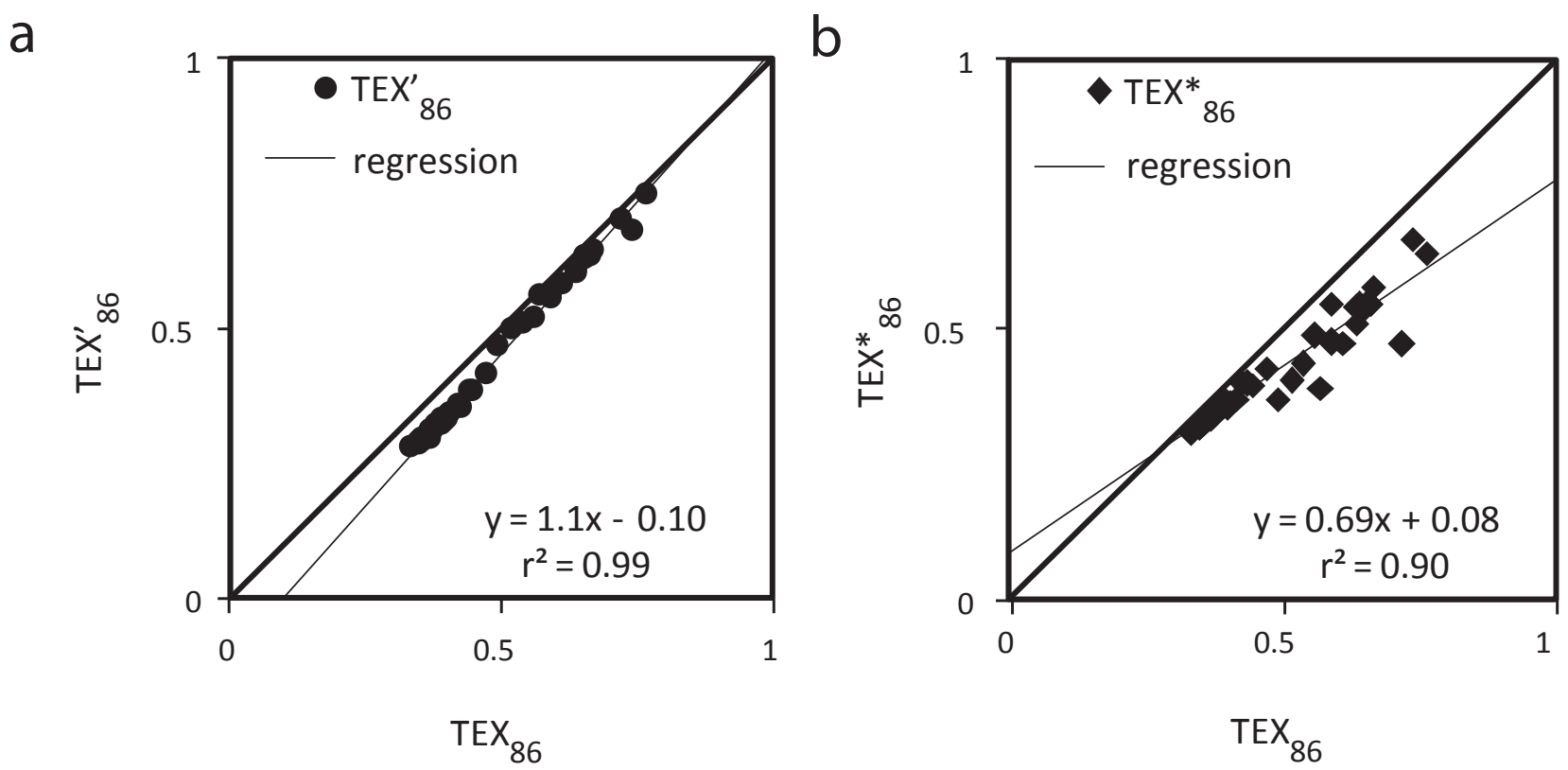


\section{ELECTRONIC ANNEX CAPTIONS}

Electronic Annex EA-1. Calculations for dilution samples measured by AMS

Electronic Annex EX-2. Relative abundances of GDGTs, $\mathrm{TEX}_{86}$ value, $\mathrm{TEX}^{*}{ }_{86}$ value and BIT values 
Shah et al. (2008) Origins of archaeal tetraether lipids in sediments: insights from radiocarbon analysis - Electronic annex EA-1

\section{ELECTRONIC ANNEX EA-1}

\section{Calculations for dilution samples measured by AMS}

Radiocarbon results from diluted samples (Table EA-1-1) were corrected for diluents following the approach outlined in Pearson et al. (1998):

$$
\Delta_{\text {sample }}=\mathrm{R}^{*} \Delta_{\text {composite }}-(\mathrm{R}-1) * \Delta_{\text {diluent }}
$$

where $\Delta^{14} \mathrm{C}$ value of sample $\mathrm{x}$ is represented as $\Delta_{\mathrm{x}}$ and $\mathrm{R}$ is the dilution factor: $\frac{\mathrm{m}_{\text {composite }}}{\mathrm{m}_{\text {sample }}}$, where $m$ refers to the mass. The uncertainty in the $\Delta^{14} \mathrm{C}_{\text {sample }}$ value is calculated from the uncertainty in the composite $\Delta^{14} \mathrm{C}$ measurement, the diluent $\Delta^{14} \mathrm{C}$ measurement and equation 1:

$$
\sigma_{\text {sample }}^{2}=\mathrm{R}^{2 *} \sigma_{\Delta_{\text {composite }}}^{2}+(1-\mathrm{R})^{2 *} \sigma_{\Delta_{\text {diluent }}}^{2}+\left(\Delta_{\text {composite }}-\Delta_{\text {diluent }}\right)^{2 *}\left(2 * \mathrm{P}^{2}\right)^{*} \mathrm{R}^{2}
$$

where $\mathrm{P}$ is the measurement precision of sample $\mathrm{x}: \mathrm{P}=\frac{\sigma_{\mathrm{x}}}{\Delta^{14} \mathrm{C}_{\mathrm{x}}}$. The $\Delta^{14} \mathrm{C}$ value of the diluent carbon was $-999 \pm 0.7 \%$ (L. Xu, personal communication).

\begin{tabular}{|c|c|c|c|c|c|c|c|}
\hline \multirow[b]{2}{*}{$\begin{array}{c}\text { Santa Monica Basin } \\
32-34 \mathrm{~cm}\end{array}$} & \multirow[b]{2}{*}{$\begin{array}{l}\text { sample size } \\
(\mu g C)\end{array}$} & \multirow[b]{2}{*}{$\mathrm{R}$} & \multirow[b]{2}{*}{$\begin{array}{l}\delta^{13} \mathrm{C} \\
(\% o)^{\dagger}\end{array}$} & \multicolumn{2}{|c|}{ composite (measured) } & \multicolumn{2}{|c|}{ sample (calculated) $)^{\ddagger}$} \\
\hline & & & & $\Delta^{14} \mathrm{C}(\%$ o $)$ & \pm & $\Delta^{14} \mathrm{C}(\% \mathrm{o})$ & \pm \\
\hline GDGT-0 & 6 & 3.35 & -21.4 & -811 & 9 & -350 & 75 \\
\hline GDGTs 1-3 & 9 & 2.42 & & -747 & 12 & -370 & 93 \\
\hline crenarchaeol & 15 & 2.00 & & -666 & 12 & -321 & 31 \\
\hline
\end{tabular}

Table EA1-1. Measurements of dilution samples and calculated $\Delta^{14} \mathrm{C}$ values

$\dagger \delta^{13} \mathrm{C}$ measured on separate split of $\mathrm{CO}_{2}$

†All calculated $\Delta^{14} \mathrm{C}$ values have been calculated using the $\delta^{13} \mathrm{C}$ value of GDGT- 0 and corrected for processing blanks. 
Shah et al. (2008) Origins of archaeal tetraether lipids in sediments: insights from radiocarbon analysis - Electronic annex EA-2

\section{ELECTRONIC ANNEX EA-2}

\section{Relative abundances of GDGTs, TEX ${ }_{86}$ value, TEX $_{86}$ value and BIT values}

Table EA2-1. Relative abundances of GDGTs, TEX $_{86}$ value, TEX $^{*}{ }_{86}$ value and BIT values

\begin{tabular}{|c|c|c|c|c|c|c|c|c|c|c|c|c|c|}
\hline \multirow[b]{2}{*}{ Core } & \multirow[b]{2}{*}{$\begin{array}{l}\text { Sediment } \\
\text { Depth }(\mathrm{cm})\end{array}$} & \multicolumn{9}{|c|}{ Abundance (relative to six GDGTs) } & \multirow[b]{2}{*}{$\mathrm{TEX}_{86}$} & \multirow[b]{2}{*}{$\begin{array}{c}\mathrm{TEX}^{*}{ }_{86} \\
\text { (no cren. } \\
\text { isomer) }\end{array}$} & \multirow[b]{2}{*}{ BIT } \\
\hline & & GDGT-0 & GDGT-1 & GDGT-2 & GDGT-3 & crenarchaeol & $\begin{array}{l}\text { cren. } \\
\text { isomer }\end{array}$ & $\mathrm{BT} \mathrm{I}^{+}$ & $\mathrm{BT} \mathrm{II}^{\ddagger}$ & BT $\|^{\S}$ & & & \\
\hline \multicolumn{14}{|c|}{ Bermuda Rise } \\
\hline $\mathrm{BC9C}$ & $0-1$ & 0.38 & 0.08 & 0.09 & 0.02 & 0.39 & 0.05 & 0.01 & 0.01 & 0.01 & 0.67 & 0.58 & 0.06 \\
\hline $\mathrm{BC} 9 \mathrm{C}$ & $1-2$ & 0.22 & 0.06 & 0.08 & 0.04 & 0.54 & 0.05 & 0.01 & 0.01 & 0.01 & 0.71 & 0.67 & 0.05 \\
\hline $\mathrm{BC} 9 \mathrm{C}$ & $3-4$ & 0.32 & 0.08 & 0.08 & 0.01 & 0.47 & 0.05 & 0.01 & 0.01 & 0.02 & 0.64 & 0.54 & 0.09 \\
\hline $\mathrm{BC9C}$ & $4-6$ & 0.31 & 0.07 & 0.07 & 0.01 & 0.50 & 0.05 & 0.01 & 0.01 & 0.02 & 0.66 & 0.54 & 0.07 \\
\hline BC9 & $6-7$ & 0.43 & 0.10 & 0.10 & 0.01 & 0.34 & 0.02 & 0.00 & 0.00 & 0.00 & 0.59 & 0.55 & 0.00 \\
\hline BC9 & $9-11$ & 0.32 & 0.08 & 0.09 & 0.01 & 0.43 & 0.06 & 0.00 & 0.00 & 0.00 & 0.66 & 0.55 & 0.01 \\
\hline BC9 & $21-23$ & 0.33 & 0.07 & 0.08 & 0.01 & 0.45 & 0.06 & 0.04 & 0.03 & 0.08 & 0.66 & 0.55 & 0.25 \\
\hline GGC5 & $192-206$ & 0.34 & 0.08 & 0.06 & 0.01 & 0.46 & 0.05 & 0.01 & 0.01 & 0.01 & 0.61 & 0.48 & 0.05 \\
\hline GGC5 & $282-292$ & 0.34 & 0.08 & 0.07 & 0.01 & 0.45 & 0.05 & 0.02 & 0.01 & 0.01 & 0.63 & 0.51 & 0.06 \\
\hline GGC5 & $350-360$ & 0.32 & 0.08 & 0.06 & 0.01 & 0.49 & 0.04 & 0.01 & 0.01 & 0.01 & 0.59 & 0.48 & 0.05 \\
\hline GPC5 & $345-355$ & 0.37 & 0.08 & 0.05 & 0.01 & 0.44 & 0.03 & 0.02 & 0.01 & 0.02 & 0.54 & 0.44 & 0.10 \\
\hline GPC5 & $907-912$ & 0.30 & 0.08 & 0.08 & 0.02 & 0.47 & 0.05 & 0.05 & 0.02 & 0.01 & 0.64 & 0.55 & 0.15 \\
\hline GPC5 & $1244-1260$ & 0.38 & 0.09 & 0.07 & 0.02 & 0.42 & 0.03 & 0.08 & 0.04 & 0.04 & 0.56 & 0.49 & 0.27 \\
\hline \multicolumn{14}{|c|}{ Santa Monica Basin } \\
\hline Pulse-32 & $0.75-1.5$ & 0.23 & 0.13 & 0.10 & 0.02 & 0.45 & 0.07 & & & & 0.59 & 0.48 & \\
\hline Pulse-32 & $1.5-2.5$ & 0.33 & 0.12 & 0.06 & 0.01 & 0.43 & 0.05 & & & & 0.49 & 0.37 & \\
\hline Pulse-32 & $2.5-3.5$ & 0.23 & 0.06 & 0.09 & 0.02 & 0.52 & 0.09 & & & & 0.77 & 0.64 & \\
\hline SMB-900 & $6-7$ & 0.45 & 0.11 & 0.07 & 0.01 & 0.32 & 0.04 & 0.03 & 0.02 & 0.01 & 0.52 & 0.41 & 0.16 \\
\hline SMB-900 & $32-34$ & 0.45 & 0.07 & 0.04 & 0.00 & 0.39 & 0.05 & & & & 0.57 & 0.39 & \\
\hline
\end{tabular}

$\uparrow$ Branched Tetraether I (Hopmans et al., 2004)

†Banched Tetraether II (Hopmans et al., 2004)

$\S$ Branched Tetraether III (Hopmans et al. 2004) 